\title{
Investigation of Stainless Steel Clad Fuel Rod Failures and Fuel Performance in the Connecticut Yankee Reactor
}

Keywords:

Fuel Performance

Stainless Steel Cladding

Fuel Pellet Densification

Stress Corrosion Cracking

Failure Analysis 
• 


\title{
Investigation of Stalnless Steel Clad \\ Fuel Rod Failures and Fuel Performance in the Connecticut Yankee Reactor
}

\author{
NP-2119 \\ Research Project 1758-1 \\ NUSCO-130 \\ Final Report, November 1981 \\ NOTICE \\ PORTIONS OF THIS REPORT ARE IIITE \\ has been reproduced from the best avn? \\ Prepared by \\ copy to permit the broadest possible avas \\ ability. \\ BATTELLE, COLUMBUS LABORATORIES \\ 505 King Avenue \\ Columbus, Ohio 43201 \\ Authors \\ V. Pasupathi \\ R. W. Klingensmith
}

EPRI-NP- -2119

DE82 901319

Prepared for

Northeast Utilities Service Company

Hartford, Connecticut 06101

Project Manager

M. T. Pitek

Electric Power Research Institute

3412 Hillview Avenue

Palo Alto, California 94304

EPRI Project Manager

H. Ocken

Materials and Corrosion Program

Nuclear Power Division

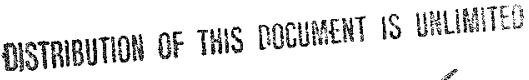

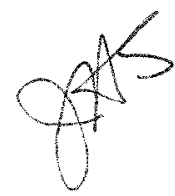




\section{ORDERING INFORMATION}

Requests for copies of this report should be directed to Research Reports Center (RRC), Box 50490, Palo Alto, CA 94303, (415) 965-4081. There is no charge for reports requested by EPRI member utilities and affiliates, contributing nonmembers, U.S. utility associations, U.S. government agencies (federal, state, and local), media, and foreign organizations with which EPRI has an information exchange agreement. On request, RRC will send a catalog of EPRI reports.

EPRI authorizes the reproduction and distribution of all or any portion of this report and the preparation of any derivative work based on this report, in each case on the condition that any such reproduction, distribution, and preparation shall acknowledge this report and EPRI as the source.

\section{NOTICE}

This report was prepared by the organization(s) named below as an account of work sponsored by the Electric Power Research Institute, Inc. (EPRI). Neither EPRI, members of EPRI, the organization(s) named below, nor any person acting on behalf of any of them: (a) makes any warranty, express or implied, with respect to the use of any information, apparatus, method, or process disclosed in this report or that such use may not infringe privately owned rights; or (b) assumes any liabilities with respect to the use of, or for damages resulting from the use of, any information, apparatus, method, or process disclosed in this report.

Prepared by

Battelle, Columbus Laboratories

Columbus, Ohio 
EPRI PERSPECTIVE

\section{PROJECT DESCRIPTION}

Nondestructive poolside examination techniques and diverse destructive examination techniques were used to characterize type-304 stainless steel clad fuel rods that were irradiated in the Connecticut Yankee PWR during cycles 7 and 8 . The fuel rod designs and operating histories were reviewed to assess their effect on fuel performance during these two operating cycles.

\section{PROJECT OBJECTIVES}

This project (RP1758-1) was supported by EPRI and Northeast Utilities Service Company. Its goals were to determine the cause of fuel rod failures in batch 8 and to establish the reasons for the different response of this fuel batch compared with earlier batches where the low primary coolant activity level indicated that fuel performance was outstanding.

\section{PROJECT RESULTS}

Failure in batch-8 fuel was caused by intergranular stress corrosion cracks that initiated at the outer surface of the cladding. The following elements played a role in contributing to the failures: (1) high localized stresses that resulted from fuel pellet chips being lodged in the fuel-to-clad gap and (2) the low propensity for in-reactor densification of the batch 8 fuel. Circumstantial evidence suggests that a power change near the end of cycle 7 (i.e., the second cycle for batch 8 rods) also may have played a role in causing the fuel rod failures. Cracks opposite fuel pellet chips also initiated at the outer surface of batch 7 fuel. Failures were not observed in this batch. Apparently, the more densification-prone fuel used in this batch led to lower imposed stresses on the cladding during operation. The data suggest the importance of the gap size under operating conditions in determining fuel performance. This gap size is affected by the microstructure of the fuel. 
To improve batch 13 fuel performance, the already-fabricated fuel and cladding will be inspected to insure that the fuel rods will be fabricated with the largest feasible fuel-to-clad gap. Evaluation of designs for batch 14 will assess the possibility of using a larger nominal fuel-clad gap and of pressurizing the fuel rods.

This report should be of interest to utility personnel with responsibilities in the areas of LWR fuel rod design and performance and those investigating BWR pipe cracking.

Howard Ocken, Project Manager

Nuclear Power Division 


\section{ACKNOWLEDGMENTS}

Many different organizations participated in this investigation. Their primary roles are briefly outlined below. The program was financed by Electric Power Research Institute (EPRI) and Northeast Utilities Service Co. (NUSCO) as agent for Connecticut Yankee Atomic Power Co. (CY). British Nuclear Fuels Limited (BNFL) provided fuel pellet fabrication information, an analys is of a power maneuvering event, and support of early in-pool rod diameter measurements. Combustion Engineering (CE) representatives conducted poolside visual fuel examinations and acted as consultants to NUSCO. Babcock \& Wilcox (B\&W) conducted pellet and cladding archive studies and provided fabrication and core power history information. General Atomic Co. also provided background fabrication information. Representatives from these organizations and from the Battelle Pacific Northwest Laboratories (PNL) were all members of the Project Review Committee that periodically reviewed experimental findings. Many individuals at these organizations contributed to the success of the project. Their efforts are gratefully acknowledged. 
-

- 
CONTENTS

Section Page

1 INTRODUCTION $1-1$

2 BACKGROUND INFORMATION 2-1

2.1 Fuel Rod Design 2-1

2.2 Operational History 2-3

2.3 Poolside Examination Results 2-4

3 BCL HOT CELL EXAMINATIONS 3-1

3.1 Fuel Assembly Receipt, Disassembly, and Fuel Rod Removal 3-1

3.2 Fuel Rod Nondestructive Examination 3-1

3.2.1 Profilometry $3-5$

3.2.2 Eddy Current Scans 3-13

3.2.3 Gamma Scans 3-13

3.2.4 Visual Examinations 3-17

3.2.5 Summary of NDE Results $3-17$

$\begin{array}{lll}3.3 & \text { Fuel Rod Destructive Examinations 3-17 }\end{array}$

3.3.1 Fission Gas Collection and Analysis, and

Void Volume Measurement $3-22$

3.3.2 Metallographic Examination 3-22

3.3.3 Fuel Density Measurements 3-42

4 DISCUSSION 4-1

4.1 Local Clad Stresses from Fuel Pellet Chips 4-2

4.2 Fuel Densification/Swelling Behavior 4-3

4.3 BNFL Analysis of Cycle 7 Power Maneuver Event 4-4

4.4 Cause of Fuel Rod Failures 4-5

4.5 Use of Research Results 4-5

5 CONCLUSIONS $5-1$

6 REFERENCES 6-1 
-

• 


\section{ILLUSTRATIONS}

Figure

$\underline{\text { Page }}$

1 Iodine-131 Activity in Primary Coolant of Connecticut Yankee Reactor

$1-2$

2 Locations of Rods Removed from Batch 8 Assembly 3-3

3 Profilometer Scan Showing Typical Ridging Observed in the Unfailed Batch 8 Rod 062E12 3-6

4 Small Diameter Increase Observed at 63-3/4 in. from Rod Bottom in the Unfailed Batch 8 Rod 157E01

5 Local Diameter and Ovality Increase Observed in the Unfailed Batch 8 Rod 062E12

$3-8$

6 Diameter Increase at the Location of Tight Axial Crack Observed in the Failed Batch 8 Rod $013 \mathrm{E} 03$

7 Examples of Ridging and Diameter Increase Observed in Unfailed Batch 8 Rod $157 E 01$ by Linear Profilometry Scan

8 Example of Ovality and Ridging and Local Diameter Increase Observed in the Unfailed Batch 7 Rod 595A10

9 Full Length Spiral Profilometry Chart Obtained on Batch 8 Rod 157E01 And Batch 7 Rod 595A12

10 Eddy Current Indication at the Location of Diameter Increase Observed in the Unfailed Batch 8 Rod 157E01

11 Gamma Scan Data Showing Depression in Activity at the Location of the Cladding Crack in the Failed Batch 8 Rod 013 E03

12 Gamma Scan Charts from Batch 7 Rod 595 A12 And Batch 8 Rod $157 E 01$

$3-16$

13 Photograph Showing a "Bump" on the Unfailed Batch 8 Rod 157E01

14 Photograph Showing a "Bump" in the Unfailed Batch 8 Rod 217 E02 at $\sim 35$ Inches from Rod Bottom

15 Appearance of the Longer of the Two Cracks Observed in Failed Rod $013 E 03$ at $\sim 25$ Inches from Rod Bottom 
16 Appearance of the Tight Crack in Rod 013 E03 at 79 Inches from Rod Bottom

17 Photomacrograph Showing the Location of Fuel Pellet-Chip in Batch 8 Rod $157 E 01$ at 64 In. from Rod Bottom

18 Appearance of Incipient Cladding Crack in Rod $157 E 01$ at 64 Inches from Rod Bottom

19 Appearance of the Two Cracks in Rod $157 \mathrm{E} 01$ at 64 Inches in Etched Condition (Etchant--Glyceregia)

20 Photomacrograph of Fuel Chip and Claddiny Crack Observed in Batch 8 Fuel Rod 217E02

21 Photo Montage of Incipient Cladding Crack in Rod 217 E02 at 24 Inches from Rod Bottom

22 Photomacrograph Showing the Location of Fuel Chip in the Unfailed Batch 3 Rod $157 E 01$ at $\sim 35-3 / 4$ Inches from Rod Bottom

23 Photo Montage of Incipient Cladding Crack Observed in Rod 157E01 at $\sim 35-3 / 4$ Inches from Rod Bottom

24 Photomacrograph Showing the Location of Fuel Chip in Batch 7 Fuel Rod 595A10

25 Appearance of Cladding Crack and Fuel Chip in Batch 7 Fuel Rod 595A10

26 Area of Tight Thruwal1 Crack in Failed Rod $013 E 03$ Showing Chip in Gap

27 Photograph Showing a Crack Branch Propagating Inward Suggesting the Origin of the Crack Shown in Figure 26 to be at the Fuel Rod Outer Surface

28 Small Tight Crack Originating at OD Adjacent to the Cladding Split Shown in Figure 26

29 0xidized $\mathrm{UO}_{2}$ Fuel at the Grain Boundaries in the Vicinity of Cladding Split in Failed Fuel Rod 013 E03

30 Appearance of Fuel Porosity at the Location of Cladding Failure in Rod $013 E 03$

31 Higher Magnification Appearance of Crack Branch Tip

32 Higher Magnification Appearance of Brittle Fracture Surface

33 Photomacrograph of Longitudinal Sample from Batch 7 Fuel Rod 595A10 Showing Axial Relocation of Fuel Pieces into the Dish

34 Results of Irradiated Fuel Density Measurements on Samples from Batch 7 and 8 Fuel Rods 


\section{TABLES}

$\underline{T a b l e}$

Page

1 Connecticut Yankee Fuel Suppliers and Design Parameters 2-2

2 Sipping Results on Batch 8 Fuel Assemblies as a Function of Burn-Up 2-5

3 Diameter Measurements Expressed as Deviations from a 0.4223 Inch Diameter Standard in Units of 0.0001 Inch

4 Identification of Fuel Rods Removed for Examination from Batch 8 Assembly $\mathrm{HO}$ and the Basis for Their Selection

5 Extent of Nondestructive/Destructive Examinations Performed on Fuel Rods Removed from Fuel Assemblies H07 and Gl1

6 Summary of NDE Data

7 Fission Gas Release and Void Volume Data Obtained on Batch 7 and Batch 8 Fuel Rods

8 Summary of Irradiated Fuel Density Measurements 
-

- 
SUMMARY

\section{BACKGROUND}

The Connecticut Yankee reactor is one of the few pressurized water reactors using stainless steel clad fuel rods. The reactor had operated essentially free of fuel rod failures up to the end of cycle 7(1969-1978). Near the end of cycle 7 an increase in primary coolant activity was observed and this increase continued during cycle 8 operation. Examination of fuel assemblies at the end of cycle 8 showed that 36 of the 48 batch 8 assemblies contained leaking fuel rods. The fuel rod failures at that time appeared limited to the batch 8 assemblies and were directly related to assembly burnup or power rating (33 out of 36 defective assemblies in the upper 60 percent of the burnup range).

\section{EXAMINATION AND RESULTS}

A detailed hot cell examination program was undertaken to determine the cause of fuel failures (in batch 8 ) and to establish differences between fuel performance in batches 7 and 8 . One fuel assembly from batch 7 (sound) and one assembly from batch 8 (leaking) were shipped to the Battelle-Columbus hot cell facility. Fuel rods removed from the two assemblies were subjected to detailed nondestructive (NDE) and destructive examinations (DE). The selection of rods and the scope of hot cell studies were based on an evaluation of results from poolside examination conducted at the reactor site. Emphasis was placed on the examination of high burnup (average > 36000 MWD/MTU) rods.

Nondestructive examinations conducted included visual examinations, fuel rod profilometry and eddy current and gamma scans. Key findings from the NDE indicated stronger clad ridging in batch 8 rods than in batch 7 rods and local clad diameter increases (indicating high local plastic strains) coincident with eddy current indications in unfailed fuel rods. In general, the fuel rods from batch 8 indicated much stronger pellet-clad interaction than batch 7 fuel rods. 
Destructive examinations performed included fission gas collection and analysis, fuel-clad metallography, and fuel density measurements. Fission gas anaiysis showed the release fractions typical of commercial power reactor fuel rods, with $<1$ percent release in batch 8 fuel rods and $\sim 4$ percent release in batch 7 fuel rods. Initially, specimens selected for metallographic examination were from the unfailed batch 8 fuel rods at the locations of eddy current indications. Three specimens from two unfailed rods were examined and all contained incipient cladding cracks. The cracks in all three specimens were directly across from a fuel chip wedged in the fuel-clad gap and were located at local diameter increases. The cracks were intergranular and originated on the outer surface of the cladding. Crack characteristics, including site of initiation (i.e. clad 0.D.), were typical of intergranular stress corrosion cracks previously observed in stainless steel cladding of BWRs.

Preliminary evaluation of the initial results suggested that the presence of fuel chips in the gap was the primary cause of fuel rod failure. However, it had been reported that fuel chipping had been a problem with previous cores as well. Thus it was necessary to establish whether batch 7 fuel rods were equally prone to develop cladding cracks. Towards this end one metallographic specimen was obtained from an unfailed batch 7 rod at the location of an eddy current indication and another from a failed batch 8 rod at the location of failure. Results from batch 7 rod metallography were very similar to those from batch 8 rods. Again, an incipient crack was found across from a fuel chip wedged in the fuel-clad gap.

It was also necessary to relate the incipient cracks to fuel rod failures consisting of long splits observed during poolside examinations. Accordingly one metallographic specimen was examined from a failed fuel rod. This specimen also showed the presence of a fuel chip in the gap adjacent to the split in the cladding. crack branches indicated that the crack had originated on the clad outer surface. Fuel in this specimen was highly oxidized due to reaction with water. It is believed that oxidation of the fuel with the resultant volume increase was responsible for the propagation of cladding splits. From the number of eddy current indications observed in a single rod, it is also possible that several independently formed cladding splits joined axially to cause the long axial splits observed in the failed fuel rods.

It is important to note that although incipient cracks were formed that were associated with a fuel chip in a batch 7 fuel rod, there was no indication of fuel 
failures in batch 7 or other previous batches which had similar fuel chipping problems during fuel rod loading. This fact suggests that fuel chips by themselves did not cause fuel failures. Other factors such as fuel swelling and irradiation history (i.e., power maneuvers) in combination with the fuel chips may have contributed to batch 8 fuel rod failures.

Fuel density measurements were made on fuel samples obtained from batch 7 and batch 8 fuel rods. Results showed a significant difference in the densification/ swelling behavior of the two fuel types. It appears that the batch 8 fuel densified by a negligible amount compared to the batch 7 fuel. The total net swelling of batch 8 fuel was higher than that of batch 7 fuel by about 0.8 percent $\Delta V / V$. This difference is equivalent to about a $1 \mathrm{mil}$ diametral difference in fuel-clad gap. This suggests that the batch 8 fuel rods operated with a smaller fuel-clad gap than the batch 7 fuel rods, resulting in relatively higher clad stresses. This interpretation is also consistent with the differences in fission gas releases observed in batch 7 and batch 8 fuel rods.

The operating history of the batch 8 fuel was also examined for any departure from ful1 power steady state operation. The most significant departure found was a 10-day period at 65 percent of full power near the end of cycle 7 . The reactor power was subsequently raised to 100 percent. The effects of this power change maneuver on fuel performance were analyzed by British Nuclear Fuels Limited (BNFL) using the SLEUTH-SEER computer code. The results indicated that this power change maneuver could have caused or initiated failures in batch 8 fuel rods. The effects of a fuel pellet chip in the gap could not be treated in this analysis. It is, however, believed that the presence of pellet chips would have exacerbated clad stresses and strains.

CAUSES OF FUEL ROD FAILURES

From an evaluation of the results, a combination of three key elements can be identified as contributing to fuel rod failures in Connecticut Yankee batch 8 fuel assemblies:

1. High localized cladding stresses resulting from fuel pellet chips wedged in the fuel-clad gap

2. Low propensity for in-reactor fuel densification of batch 8 fuel

3. Power change maneuver near the end of cycle 7 (2nd cycle for batch 8 rods). 
The extent of contribution from item 3 above is not clear. Results from nondestructive and destructive examinations indicate that fuel-clad interaction was significantly stronger in batch 8 rods than in batch 7 . Thus contributions from 1 and 2 above are believed to be sufficient to cause failures. However, in view of the fact that the initial increase in coolant activity was observed following the power change maneuver, possible contributions from this event cannot be ruled out.

The sequence of events leading to the observed failures may be summarized as shown in Figure $\mathrm{S}-1$.

APPLICATION OF RESULTS

These results have led to selected fabrication adjustments and surveillance programs intended to mitigate the pellet chipping problem. In addition, design 'refinements' within current specifications to improve batch 13 fuel performance have been instituted. More extensive design and fabrication changes are planned for future reload batches. 


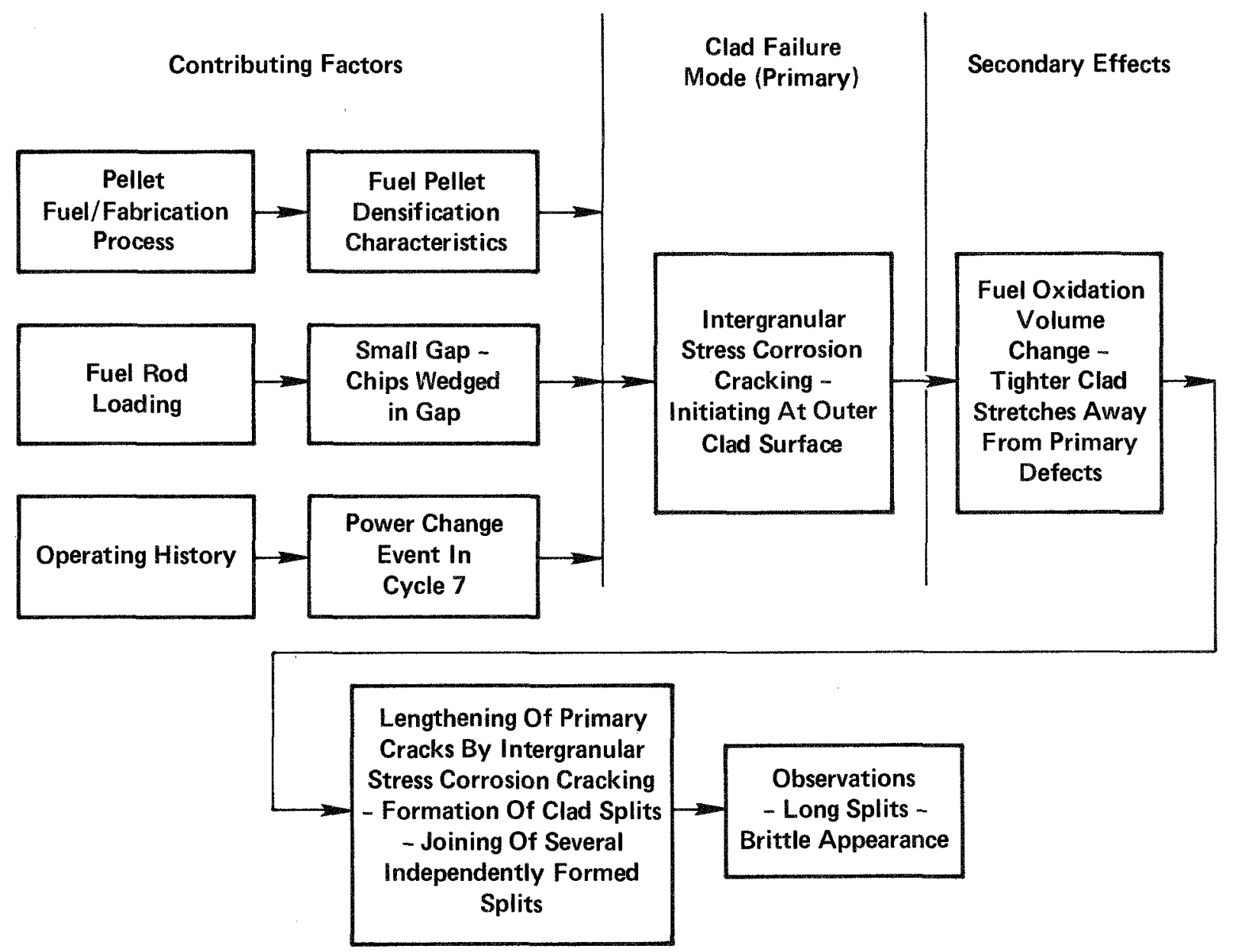

FIGURE S-1. Batch 8 Fuel Rod Failure Event Tree 
-

• 
Section 1

INTRODUCTION

Prior to cycle 7, the Connecticut Yankee reactor, which uses stainless steel clad fuel rods, had operated essentially free of fuel rod failures. Near the end of cycle 7 , an increase in coolant activity was observed. This increase continued during cycle 8 (Figure 1). Examination of the coolant activity data showed that a large portion of the activity was due to the recoil process (evidenced by low I131/I133 ratios and the presence of Np239 in the coolant), indicating that the fuel in the failed rods was directly exposed to the coolant. Also, a high Cs134/ Cs137 activity ratio indicated that the source of the activity was high burnup fuel (probably from batch 8 ) (1).

At the end of cycle 8, all the discharged batch 8 and selected batch 7 and batch 9 fuel assemblies were leak tested by using a wet sipping system. The results showed that 36 of the 48 batch 8 fuel assemblies ( 75 percent) were leaking, while all six of the batch 7 and batch 9 fuel assemblies which were sipped were sound(1). Four of the batch 7 fuel assemblies sipped had undergone three cycles of operation. Therefore, fuel rod failures at the time appeared unique to batch 8 fuel assemblies. More recent examinations performed after cycle 9 operation, however, have indicated fuel rod failures in batch 9 assemblies(2).

After leak testing, a number of batch 8 fuel assemblies were visually examined using an underwater television system in the spent fuel pool. In four of the assemblies, failed rods were observed--two rods each in three assemblies and eight rods in the fourth. All failures were in the form of axial cladding cracks of various lengths and widths and of a brittle nature. Some of the cracks appeared to spiral along the rod length. On some of the rods multiple cracks were observed at the same axial location.

While the data obtained from the poolside examination indicated the general features of the fuel rod failures, the cause of failure could not be identified. Hence, batch 8 fabrication data were reviewed, and reactor operational data for cycles 7 and 8 were analyzed. Based on the results of these efforts, it was 


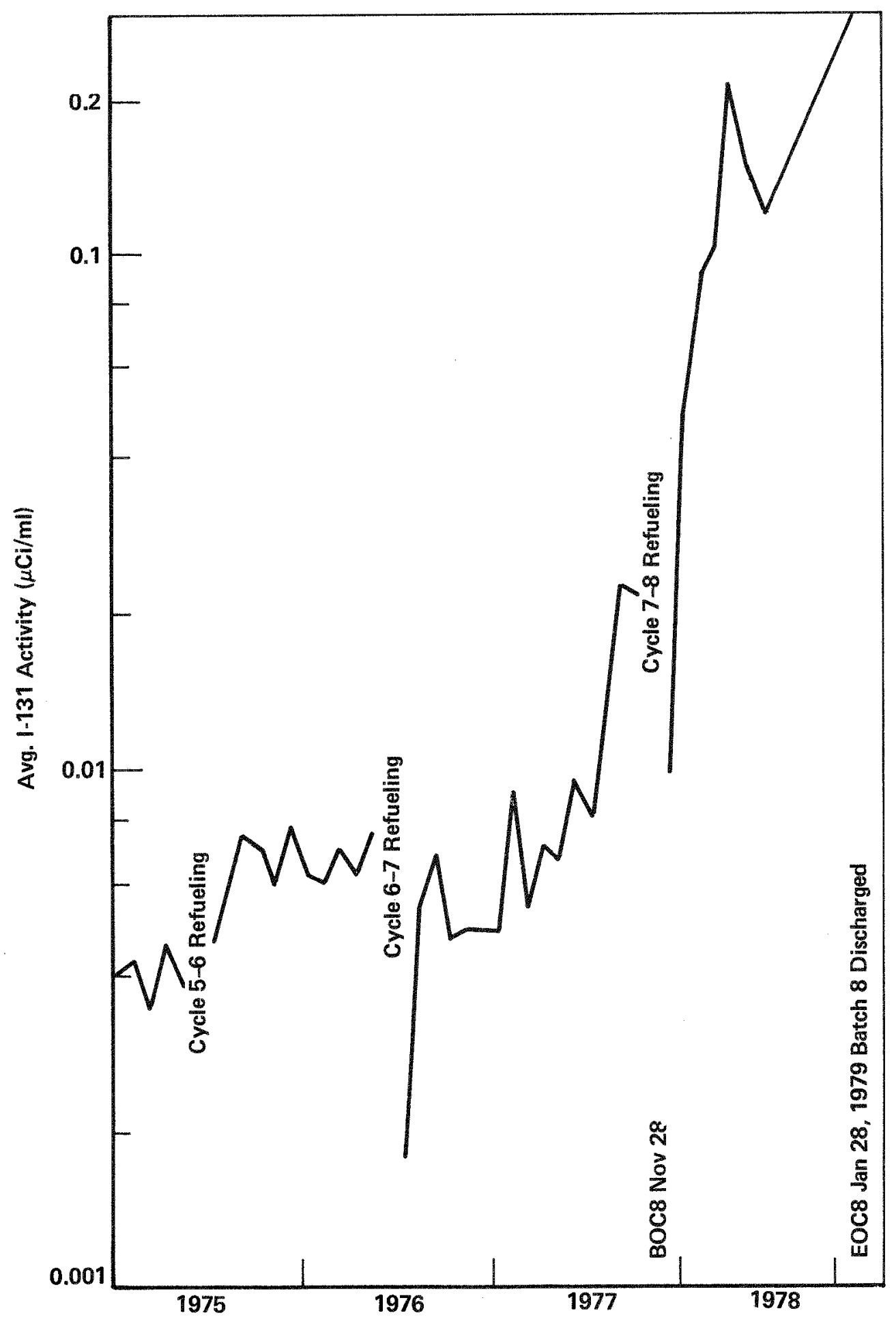

FIGURE 1. lodine-131 Activity In Primary Coolant of Connecticut Yankee Reactor 
postulated that the failures could have been caused by a power ramp near the end of cycle 7 or by a "wear-out" or "life-limiting" mechanism. In any case, further investigations, including hot cell examination, were deemed necessary to clearly identify the failure mechanism. As an interim measure, restrictions on the rate of power increase for the Connecticut Yankee reactor were imposed to prevent failures in future operating cycles.

A more detailed poolside examination was undertaken, leading to the selection of two fuel assemblies, one batch 7 and one batch 8, for hot cell examinations. Both were three-cycle assemblies. The batch 8 assembly contained several visually observed failed fuel rods. The two fuel assemblies were shipped to BCL for hot cell examinations. A third assembly from batch 5 (qualification assembly s004) was also included in the shipment to study long-term storage effects under a program funded by DOE.

The objectives of the hot cell examinations were to:

1. Identify the cause of fuel rod failures in batch 8

2. Establish what $\mathrm{UO}_{2}$ fuel differences, if any, between batches 7 and 8 could have contributed to the failures

3. Identify changes required in fuel rod design and/or reactor operation to avoid failures in future cycles.

The hot cell examination was carried out in two phases. An interim report was issued at the conclusion of the first phase(3). This final report presents the main findings and conclusions from both phases of the program. 
-

- 
Section 2

BACKGROUND INFORMATION

Before shipping any of the fuel assemblies to Battelle's Columbus Laboratories $(B C L)$ for hot cell examinations, a detailed evaluation of fabrication data, operating history, and poolside examination results was conducted. These data were also used to establish the scope of the hot cell examination. Thus it is important to provide pertinent background information about the batch 7 and batch 8 fuel assemblies. Similar information on the batch 5 qualification assembly S004 will be documented in a separate report being prepared for the Department of Energy.

\subsection{FUEL ROD DESIGN}

Details of the Connecticut Yankee fuel rod design are documented in the interim report( $(\underline{3})$. Only the highlights wîl be presented here.

Table 1 summarizes the design parameters and lists the various fuel vendors for the Connecticut Yankee cores.

Fuel rods for the first six batches were designed and fabricated by westinghouse. The fuel pellets and the rods for batch 7 were fabricated by Gulf-United Nuclear Fuels (GUNF). Batch 8 fuel pellets were fabricated by British Nuclear Fuels Limited (BNFL) and assembled into rods by Gulf-United Nuclear and Babcock and Wilcox Company (B\&W). Fuel rods for batches 9 through 12 were fabricated by Babcock and Wilcox. The cold-worked type 304 stainless steel cladding (weld drawn) for all batches (except qualification assemblies) was supplied by Superior Tube Company.

A detailed review of available manufacturing information, specifications, QA records, and as-built data was performed by B\&W and Northeast Utilities. Examination of archive pellet and cladding samples from batches 7, 8, and 9 was performed by $B \& W(\underline{4})$.

Examination of as-built data and manufacturing information on the pellets showed batch 8 pellets to be somewhat different from those of batches 7 and 9 . The batch 
TABLE 1

CONNECTICUT YANKEE FUEL SUPPLIERS AND DESIGN PARAMETERS

\begin{tabular}{|c|c|c|c|c|c|c|c|c|c|c|c|c|}
\hline Batch Designation & 1 & 2 & 3 & 4 & $4 \mathrm{~N}$ & $4 \mathrm{~A}$ & $5 / 7 A$ & $\begin{array}{c}5 G \\
(S 004)\end{array}$ & $5 A$ & $6{ }_{7 \mathrm{~B}}^{6 \mathrm{~A}}$ & $7 / 7 \mathrm{C}$ & 8 \\
\hline Fuel contractor & Westingho & use $(W)-$ & S & $\longrightarrow$ & - NUMEC & NUMEC & W & GGA & GGA & W & GUNF - & \\
\hline Fuel pellet supplier & Westingho & use $(W)-$ & 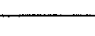 & $\longrightarrow$ & - NUMEC & NUMEC & w & BNFL & BNFL & $w$ & GUNF & BNFL \\
\hline Fuel clad supplier & Superior $\mathrm{T}$ & be Compan & & 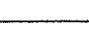 & $-?$ & $?$ & Superior & $?$ & $?$ & Superior & & 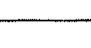 \\
\hline Fuel assembly fabricator & Westingho & use $(W)$ & 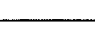 & $\rightarrow$ & - NUMEC & NUMEC & w & BNFL & BNFL & w & GUNF & $\mathrm{B} \& \mathrm{~W}$ \\
\hline Number of assemblies & 53 & 52 & $52^{*}$ & 48 & 2 & 2 & $49 / 1$ & 1 & 2 & $50 / 2$ & $51 / 2$ & 48 \\
\hline Enrichment, w/o & 3.00 & 3.24 & 3.67 & & & 3.00 & 4.00 & 4.00 & 3.25 & $4.0 / 3.67$ & $4.0 / 3.66$ & 4.0 \\
\hline Fuel density, $\%$ & 93.0 & 94.0 & 94.0 & 92.8 & 93.2 & 92.4 & 92.9 & 93.2 & 93.0 & $92.7 / 92.8$ & $94.85 / 94.57$ & 95.17 \\
\hline Initial pressure osia & $147>2>3$ & & & & & \multicolumn{7}{|c|}{ Some, 200 psi } \\
\hline Fill gas & Air - & S & 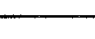 & - & $-\mathrm{He}$ & $\mathrm{He}$ & Air & $\mathrm{He}$ & $\mathrm{He}$ & Air & $\mathrm{He} / \mathrm{Ar} / \mathrm{Air}$ & \\
\hline Stack height, in. & 121.8 & 121.8 & 121.8 & 120.0 & 119.3 & 118.4 & 120.0 & 121.5 & 121.1 & 120.0 & $120.3-$ & \\
\hline Pellet diameter, in. & 0.3835 & 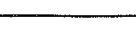 & & & 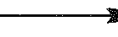 & -0.3680 & 0.3835 & - & -0.3645 & 0.3835 & & \\
\hline Pellet length, in. & 0.600 & & & & & & & -0.450 & - & $\rightarrow 0.600$ & 0.420 & \\
\hline Cladding mat'l & ss & ss & $\mathrm{SS}^{*}$ & ss & SS & Zirc & SS & SS & Zirc & SS & SS & \\
\hline Clad thickness, in. & 0.0165 & 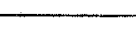 & & & - & -0.024 & 0.0165 & 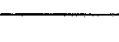 & -0.025 & 0.0165 & & \\
\hline Clad I.D., in. & $0.389-$ & 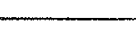 & 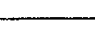 & 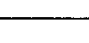 & - & 0.374 & 0.389 & 0.3905 & 0.3735 & 0.389 & & \\
\hline Gap diameter, in. & 0.0055 & 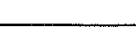 & & & 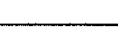 & -0.006 & 0.0055 & 0.007 & 0.009 & 0.0055 & & \\
\hline
\end{tabular}

${ }^{*}$ Four assemblies contain four Zircaloy test rods each.

$W$-Westinghouse

GGA-Gulf General Atomic.

BNFL-British Nuclear Fuels Limited.

B\&W-Babcock and Wilcox.

GUNF-Gulf United Nuclear Fuels. 
8 pellets were manufactured by BNFL using a controlled porosity (CONPOR) process. However, all fuel rod specifications checked were fully satisfied.

Investigations conducted by $B \& W$ on archive pellets also showed some differences between batch 8 pellets and those from batches 7 and 9 . Batch 8 fuel pellets, in comparison to batch 7 and 9 pellets, appeared to contain a higher percentage of larger pores in a high-density matrix, probably because of the use of a pore former during fabrication. Quantitative analysis of the photographs (on the Quantimet) also confirmed this observation. In batch 8 pellets, 50-60 percent of the porosity was in the 5-10 $\mu \mathrm{m}$ range, while in pellets from batches 7 and 9 , 70-80 percent of the porosity was in the 1-5 $\mu \mathrm{m}$ range. The larger fraction of small pores $(1-5 \mu \mathrm{m})$ observed in pellets from batches 7 and 9 compared to batch 8 pellets suggests that fuel from the former may be more densifying in-reactor than is the batch 8 fuel. One aspect of lower in-reactor densification is that it results in fuel-cladding contact earlier in the assembly's life and therefore produces higher cladding stresses at higher burnups.

Thermal resintering tests were performed on pellet samples from batches 8 and 9 . Batch 7 pellets were not available for testing. Tests were conducted for 6 and 24 hours both at $1600 \mathrm{C}$ and $1700 \mathrm{C}$. Results showed no significant differences in the measured density changes. For batch 8 fuel, the increase in density after 24 hours at $1700 \mathrm{C}$ ranged from 1.18 to 1.43 percent. For batch 9 it was 1.43 percent.

\subsection{OPERATIONAL HISTORY}

A review of the power history of batch 8 and 9 fuel rods was performed by Northeast Utilities. The cycle average linear heat ratings for the second and third cycle operation of batch 8 rods were 6.6 and $5.5 \mathrm{kw} / \mathrm{ft}$, respectively. Batch 9 rods experienced $6.5 \mathrm{kw} / \mathrm{ft}$ during their second cycle of irradiation. Results of the review indicated that the linear rating experienced by the batch 8 rods was quite typical of commercial power reactor fuel rods.

The operating history of batch 8 fuel was al so examined for any departures from steady-state ful1-power operation. The most significant departure was a 10-day period at 65 percent of full power near the end of cycle 7 (near the end of the second cycle for batch 8 fuel). The reactor power was subsequently raised to 100 percent very rapidly. It has been hypothesized that this power ramp could have caused or initiated the failures in batch 8 fuel (since increase in coolant 
activity was observed shortly after this event) by inducing excessive local clad strains adjacent to radial pellet cracks. It was, however, concluded that additional efforts were needed to verify this hypothesis.

\subsection{POOLSIDE EXAMINATION RESULTS}

At the end of cycle 8, all of the batch 8 fuel assemblies and six batch 7 and 9 fuel assemblies were leak tested by a wet-sipping technique. Leakers were found only among the batch 8 fuel assemblies. In all, 36 of the 48 batch 8 assemblies were positively identified as leaking. Results, shown in Table 2, al so indicate a definite correlation between fuel assembly burnup or power rating and the frequency of leakers.

At an assemb7y burnup of 34,200 MWD/MTU and above, all assemblies (a total of 20) were found to be leaking. Between burnups of 32,400 and 34,200 MWD/MTU, 13 of the 16 assemblies were leaking. At burnups below 32,400 MWD/MTU, only 3 of 12 assemblies were found to be leaking.

At the conclusion of the sipping tests, 24 batch 8 fuel assemblies were visually examined using underwater television equipment in the spent fuel pool. Failed fuel rods were observed in four fuel assemblies. Three assemblies each contained two failed rods and the fourth contained eight failed rods. All four assemblies had been classified as leakers from the sipping examination, and all failures were in the form of axial cladding cracks of varying lengths and widths and of a brittle nature. Some of the cracks appeared to spiral along the rod length. Multiple cracks were observed in some rods at the same axial location.

After the initial visual examination, portable fuel rod diameter measurement equipment, designed and built by Windscale Nuclear Power Development Laboratories (WNL) (UKAEA) under contract to BNFL Fuels Division, was used to determine whether any unusual fuel swelling had taken place. Measurements were taken on the outer row of fuel rods of two 3 cycle batch 8 assemblies (containing BNFL CONPOR fuel) and one 2 cycle batch 9 assembly. Two hundred diameters were measured on a total of 63 fuel rods in 9 faces of these three $15 \times 15$ pressurized water reactor fuel assemblies, with a reproducibility of typically 0.0001 in. The results showed that compared with the plenum diameters fuel cladding had undergone compressive creepdown over the highly rated zones of the fuel length. Three cycle batch 8 rods containing BNFL fuel typically exhibited 0.001-in.-diameter reduction, while 
TABLE 2

SIPPING RESULTS ON BATCH 8 FUEL ASSEMBLIES

AS A FUNCTION OF BURN-UP

\begin{tabular}{|c|c|c|}
\hline $\begin{array}{c}\text { Assembly Burn-Up } \\
\text { (MWD/MTU) }\end{array}$ & Leaking & Sound \\
\hline 35,800 & H07, H21, H31, H38 & \\
\hline 35,000 & $\mathrm{HO}, \mathrm{H} 23, \mathrm{H} 4 \mathrm{O}, \mathrm{H} 53$ & \\
\hline 34,300 & $\mathrm{H} 16, \mathrm{H} 2 \mathrm{O}, \mathrm{H} 33, \mathrm{H} 35$ & \\
\hline 34,200 & H05, H13, H15, H24, H3O, H37, H43, H44 & \\
\hline 32,500 & $\mathrm{H} 10, \mathrm{H} 14, \mathrm{H} 22, \mathrm{H} 28, \mathrm{H} 29, \mathrm{H} 32$ & $\mathrm{H} 45, \mathrm{H} 50$ \\
\hline 32,400 & $\mathrm{H} 11, \mathrm{H} 18, \mathrm{H} 25, \mathrm{H} 27, \mathrm{H} 41, \mathrm{H} 45, \mathrm{H} 52$ & H36 \\
\hline 31,500 & $\mathrm{H} 26, \mathrm{H} 34$ & $\mathrm{H} 04, \mathrm{H} 06, \mathrm{H} 17, \mathrm{H} 39, \mathrm{H} 42, \mathrm{H} 51$ \\
\hline 30.100 & & $\mathrm{H} 12, \mathrm{H} 19, \mathrm{H} 49$ \\
\hline 29,800 & $\begin{array}{l}\text { H01 } \\
36 \text { Leaking }\end{array}$ & 12 Sound \\
\hline
\end{tabular}


2 cycle batch 9 rods of the same design showed reductions of 0.002 to 0.004 inches(5). These results are shown in Table 3 .

Subsequently, a more detailed examination of six leaking assemblies and a review of the available preirradiation data on them were carried out to select an assembly for hot cell examinations and to characterize cladding damage and better identify failed fuel rods. Batch 8 fuel assembly 107 was selected for the following reasons:

- $H 07$ was in the highest burnup assembly group and had no grossly damaged peripheral rods that could complicate later handling.

- H07 contained a broad representation of the batch 8 pellet and cladding lots, including combinations of lots with a relatively high propensity for early fuel-clad gap closure (i.e., low $\mathrm{UO}_{2}$ densification with small clad inner diameter).

- H07 contained the only rod with a single cladding crack that might be the primary failure and had seven failed rods identified in the visual examination. (The probability of finding evidence of incipient failure in this assembly was believed to be at least as high as for any other assembly in the highest burnup group.)

Batch 7 assembly G1I was also selected for detailed examination in the hot cell. This assembly was from the highest burnup group $(36,700$ MWD/MTU) and was confirmed to be sound by sipping. It would thus serve as a baseline with which results obtained from the examination of batch 8 assembly $H 07$ could be compared. In addition, the assembly contained rods with cladding from the same tube lot as those in assembly H07. 
TABLE 3

DIAMETER MEASUREMENTS EXPRESSED AS DEVIATIONS FROM A 0.4223 " DIAM. STANDARD IN UNITS OF 0.0001"

\begin{tabular}{|c|c|c|c|c|c|c|c|}
\hline \multirow[b]{2}{*}{ Face } & \multirow[b]{2}{*}{ Rod No. } & \multicolumn{2}{|c|}{ Assembly $\mathrm{HO}^{+}$} & \multicolumn{2}{|c|}{ Assembly $\mathrm{H} 53^{+}$} & \multicolumn{2}{|c|}{ Assembly $140^{x}$} \\
\hline & & Plenum & Span 3 & Plenum & Span 4 & Plenum & Span 4 \\
\hline \multirow[t]{4}{*}{ North } & $\begin{array}{c}5 \\
6 \\
7 \\
8 \\
9 \\
10 \\
11 \\
\end{array}$ & $\begin{array}{l}+3 \\
+10 \\
+3 \\
+7 \\
+8 \\
+2 \\
+5\end{array}$ & $\begin{array}{l}-14(-14) \\
0 \\
-9 \\
-12 \\
-3 \\
+5 \\
-8\end{array}$ & $\begin{array}{l}- \\
- \\
- \\
- \\
-\end{array}$ & $\begin{array}{l}- \\
- \\
- \\
- \\
-\end{array}$ & $\begin{array}{l}- \\
- \\
- \\
- \\
-\end{array}$ & $\begin{array}{l}- \\
- \\
- \\
- \\
-\end{array}$ \\
\hline & $\overline{\mathrm{x}}$ & +5.4 & -5.9 & - & - & - & - \\
\hline & $\sigma \tilde{\mathrm{x}}$ & 1.1 & 2.6 & - & - & - & - \\
\hline & & Plenum & Span 4 & Plenum & Span 4 & Plenum & Span 4 \\
\hline \multirow[t]{4}{*}{ East } & $\begin{array}{c}5 \\
6 \\
7 \\
8 \\
9 \\
10 \\
11 \\
\end{array}$ & $\begin{array}{l}+10(+10) \\
+9 \\
+5 \\
+4 \\
+4 \\
+7 \\
+5 \\
\end{array}$ & $\begin{array}{l}-8 \\
-2 \\
-6 \\
-13 \\
-11 \\
-6 \\
-12 \\
\end{array}$ & $\begin{array}{l}+6 \\
+10 \\
+6 \\
+4 \\
+2 \\
+1 \\
+2 \\
\end{array}$ & $\begin{array}{l}-9 \\
-14 \\
-16 \\
-1 \\
-7 \\
-5 \\
-16 \\
\end{array}$ & $\begin{array}{l}- \\
- \\
- \\
- \\
- \\
-\end{array}$ & $\begin{array}{l}- \\
- \\
- \\
- \\
-\end{array}$ \\
\hline & $\overline{\bar{x}}$ & +6.3 & -8.3 & +4.4 & -9.7 & - & - \\
\hline & $\sigma \tilde{\bar{x}}$ & 0.9 & 1.5 & 1.2 & 2.2 & - & 二 \\
\hline & & Plenum & Span 4 & Plenum & Span 4 & Plenum & Span 4 \\
\hline \multirow[t]{4}{*}{ South } & $\begin{array}{c}5 \\
6 \\
7 \\
8 \\
9 \\
10 \\
11 \\
\end{array}$ & $\begin{array}{l}+2(+1) \\
+4 \\
+12(+12) \\
+5 \\
+3 \\
-3 \\
-1\end{array}$ & $\begin{array}{l}-3 \\
-10 \\
-3 \\
-7 \\
-17 \\
-12 \\
-14 \\
\end{array}$ & $\begin{array}{l}+7 \\
+6 \\
-3 \\
-1 \\
-4 \\
+1 \\
-4(-5) \\
\end{array}$ & $\begin{array}{l}0 \\
-5 \\
-13 \\
-10 \\
-6 \\
-4 \\
-14 \\
\end{array}$ & $\begin{array}{l}-4 \\
-5 \\
-7 \\
-9(-6) \\
+1 \\
-5 \\
-4(-2) \\
\end{array}$ & $\begin{array}{l}-8(-9) \\
-49(-47) \\
-23(-24) \\
-47(-47) \\
-30(-29) \\
-30(-28) \\
-39(-39)\end{array}$ \\
\hline & $\bar{x}$ & +3.1 & -9.4 & +0.3 & -7.4 & -4.7 & -32.4 \\
\hline & $\sigma \bar{x}$ & 1.8 & 2.0 & 1.7 & 1.9 & 1.2 & 5.3 \\
\hline & & Plenum & Span 4 & Plenum & Span 4 & Plenum & Span 4 \\
\hline \multirow[t]{3}{*}{ West } & $\begin{array}{c}5 \\
6 \\
7 \\
8 \\
9 \\
10 \\
11\end{array}$ & $\begin{array}{l}+3 \\
+3 \\
0 \\
+4 \\
-1 \\
+5 \\
+5\end{array}$ & $\begin{array}{l}-7 \\
-13 \\
-7 \\
-8 \\
-14 \\
-9 \\
-3\end{array}$ & $\begin{array}{l}-1 \\
+3 \\
-2 \\
0 \\
+2 \\
-2 \\
-2\end{array}$ & $\begin{array}{l}-20(-20) \\
-5 \\
-11 \\
-20(-20) \\
-3 \\
-13 \\
-11\end{array}$ & $\begin{array}{c}-5 \\
-3 \\
0 \\
+4 \\
-1 \\
-1 \\
+6\end{array}$ & $\begin{array}{l}+5 \\
-40(-34) \\
+3(+5) \\
-35 \\
-41 \\
-41 \\
-33(-36)\end{array}$ \\
\hline & $\overline{\mathrm{x}}$ & +2.7 & -8.7 & $-0 . \overline{3}$ & -11.9 & 0 & -26.0 \\
\hline & $\sigma \bar{x}$ & 0.9 & 1.4 & 0.8 & 2.5 & 1.4 & 7.8 \\
\hline
\end{tabular}

$+=$ BNFL CONPOR fueled rods

$\mathrm{x}=$ Babcock and Wilcox rods 
-

- 
Section 3

BCL HOT CELL EXAMINATIONS

\subsection{FUEL ASSEMBLY RECEIPT, DISASSEMBLY, AND FUEL ROD REMOVAL}

Fuel assemblies H07 and Gll were shipped dry to BCL. After receipt and unloading, the fuel assemblies were transferred into the hot cell. To facilitate removal of fuel rods the top end was disassembled by removing the upper nozzle. No problems were encountered during removal of the upper nozzle.

Initially, two peripheral rods were removed from assembly H07. These rods were previously identified as failed during poolside visual inspection. They were removed to verify assembly orientation and to locate unfailed candidate rods for examination. Also, one of these failed rods appeared to have only one crack, which was believed to be a primary defect and therefore of interest in determining the cause of failure. Subsequently, additional unfailed rods were removed and subjected to detailed examinations. Selection of these rods was based primarily on fuel rod burnup. Other reasons for selecting them included pellet and tube lot characteristics and proximity to failed fuel rods. Table 4 shows which rods were removed for examination and the basis for their selection. Figure 2 shows the location of rods removed from assembly HO7.

Four fuel rods were removed from assembly G11. These rods had a range of burnups with two in the highest burnup group. In addition, all four rods contained fuel pellets from lot 512, for which thermal resintering data were available.

\subsection{FUEL ROD NONDESTRUCTIVE EXAMINATION}

Selected fuel rods removed from the two assemblies were subjected to detailed nondestructive examinations (NDE) to locate and identify any anomalies in the rods. These examinations included profilometry, gamma scans, eddy current scans (encircling coil and probe coil) and stereovisual examinations. Table 5 shows the extent of NDE/DE performed on the rods. Procedures used for the NDE have been documented in the interim report. Only the key results are discussed here. 
TABLE 4

IDENTIFICATION OF FUEL RODS REMOVED FOR EXAMINATION FROM BATCH 8 ASSEMBLY HO7 AND THE BASIS FOR THEIR SELECTION

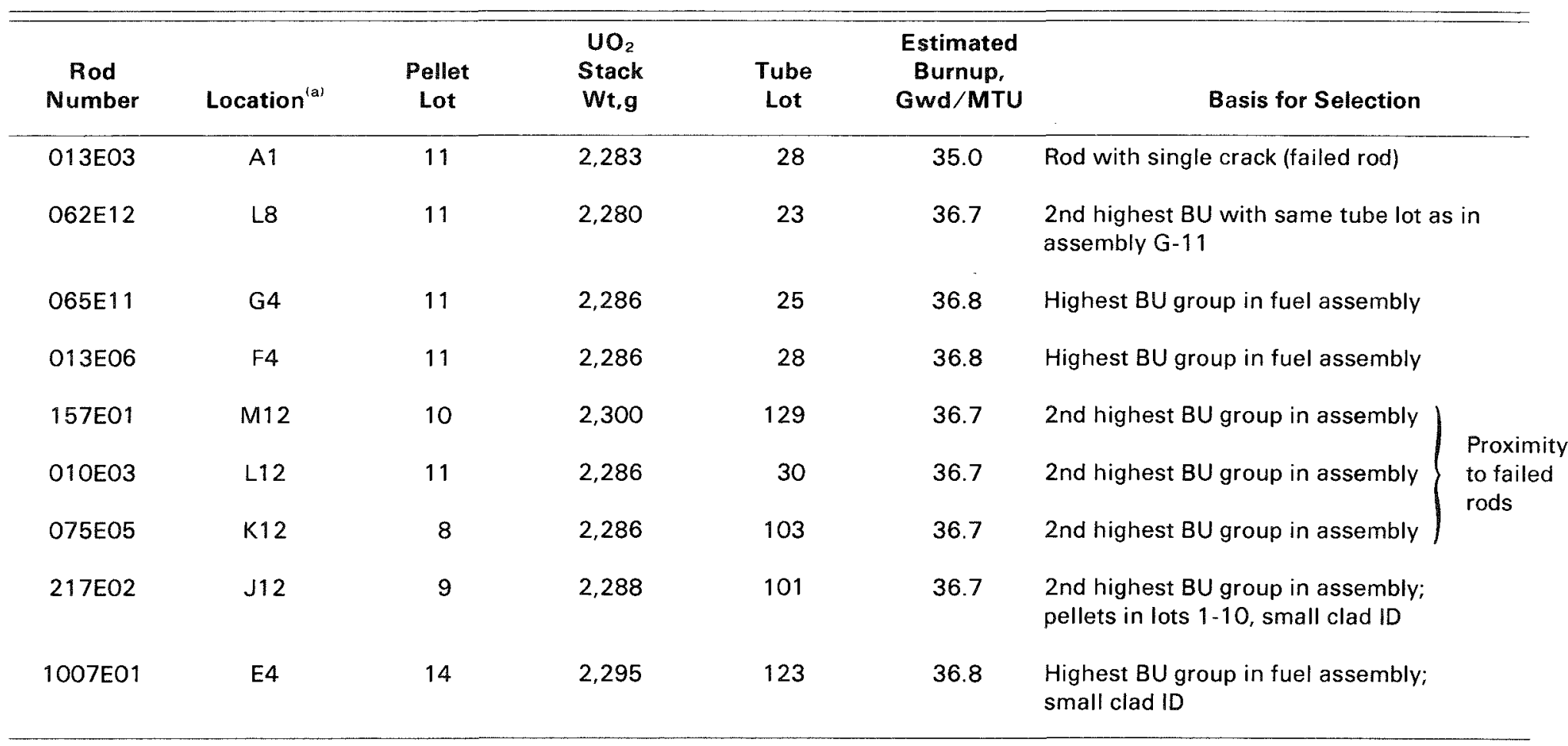

(a) See Figure 2 for rod array in assembly $\mathrm{HO}$. 


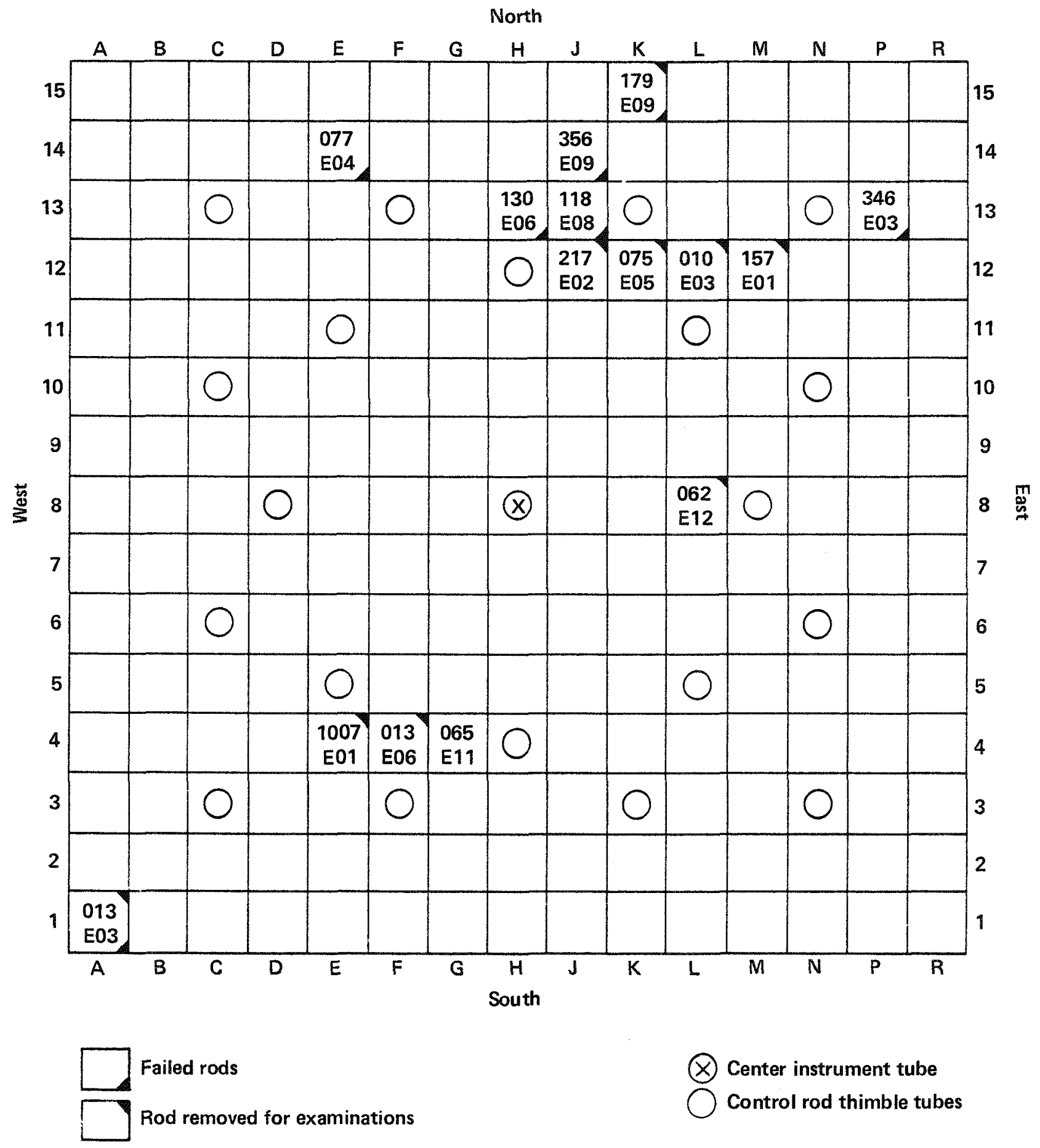

FIGURE 2. Locations Of Rods Removed From Batch 8 Assembly 
TABLE 5

EXTENT OF NONDESTRUCTIVE/DESTRUCTIVE EXAMINATIONS PERFORMED ON FUEL RODS REMOVED FROM FUEL ASSEMBLIES HO7 AND G11

\begin{tabular}{|c|c|c|c|c|c|c|c|c|c|c|c|}
\hline \multirow[b]{2}{*}{ Rod No. } & \multirow[b]{2}{*}{ Position } & \multirow[b]{2}{*}{$\begin{array}{l}\text { Known } \\
\text { Failed }\end{array}$} & \multicolumn{6}{|c|}{ NDE } & \multirow[b]{2}{*}{ Comment } & \multirow[b]{2}{*}{ Metallograph } & \multirow[b]{2}{*}{ Density } \\
\hline & & & Profile & $\begin{array}{l}\text { Coil } \\
\text { E.C. }\end{array}$ & $\begin{array}{l}\text { Probe } \\
\text { E.C. }\end{array}$ & $\begin{array}{c}\text { Detailed } \\
\text { Visual }\end{array}$ & $\begin{array}{l}\text { F.G. } \\
\text { Punch }\end{array}$ & $\lambda$-Scan & & & \\
\hline \multicolumn{12}{|l|}{ Assy $\mathrm{HO} 7$} \\
\hline 013Е03 & $\mathrm{A} 1$ & Yes & $x$ & $x$ & & $x$ & & $x$ & $\begin{array}{l}\text { Destructively } \\
\text { examined }\end{array}$ & $x$ & \\
\hline $179 \mathrm{EO} 9$ & K15 & Yes & & & & & & & $\begin{array}{l}\text { Removed } \\
\text { in storage }\end{array}$ & & \\
\hline O62E12 & L8 & No & $x$ & $x$ & $x$ & $x$ & $x$ & $x$ & Candidate rod & & \\
\hline 065E11 & G4 & No & $x$ & & & & & & Reinserted & & \\
\hline $013 E 06$ & $\mathrm{~F} 4$ & No & $x$ & $x$ & & & & & $\begin{array}{l}\text { Removed } \\
\text { in storage }\end{array}$ & & \\
\hline 157E01 & M12 & No & $x$ & $x$ & $x$ & $x$ & $x$ & & $\begin{array}{l}\text { Destructively } \\
\text { examined }\end{array}$ & $x$ & \\
\hline 010E03 & L12 & No & $x$ & $x$ & $x$ & & & & $\begin{array}{l}\text { Removed } \\
\text { in storage }\end{array}$ & & \\
\hline 075E05 & $\mathrm{K} 12$ & No & $x$ & $x$ & & & & & Reinserted & & \\
\hline 217EO2 & $J 12$ & No & $x$ & $x$ & $x$ & $x$ & $x$ & $x$ & examined & $x$ & $x$ \\
\hline $1007 \mathrm{E} 1$ & E4 & No & $x$ & $\mathrm{x}$ & & & & & $\begin{array}{l}\text { Removed } \\
\text { in storage }\end{array}$ & & \\
\hline \multicolumn{12}{|l|}{ Assy G-11 } \\
\hline $595 \mathrm{~A} 1$ & R11 & No & & & & & & $x$ & $\begin{array}{l}\text { Removed } \\
\text { in storage }\end{array}$ & & \\
\hline $595 \mathrm{~A} 10$ & $\mathrm{H} 11$ & No & $x$ & $x$ & & $x$ & $x$ & $x$ & $\begin{array}{l}\text { Destructively } \\
\text { examined }\end{array}$ & $x$ & $x$ \\
\hline $595 A 11$ & G11 & No & & & & & & & $\begin{array}{l}\text { Removed } \\
\text { in storage }\end{array}$ & & \\
\hline $595 \mathrm{~A} 12$ & F11 & No & $x$ & $x$ & & & & $x$ & $\begin{array}{l}\text { Removed } \\
\text { in storage }\end{array}$ & & \\
\hline
\end{tabular}




\subsubsection{Profilometry}

Eleven rods were profiled to detect and characterize any local fuel rod diameter anomaly and to determine the extent of cladding creepdown over the full length of the rod. All batch 8 fuel rods showed significant clad ridging at fuel pellet interfaces. The typical ridge height (relative to fuel rod diameter at mid-pellet region) was approximately $1 \mathrm{mil}$. Fuel rod ovality was rather 1 ow, less than about $4 \mathrm{mils}$ at the top and bottom ends and about 0.5 to $1 \mathrm{mil}$ in the midregions. Fuel rod average creepdown based on the diameter measured in the plenum was in the range of 1 to 1.5 mils. These are in agreement with the poolside measurements shown in Table 3.

In addition to clad ridging, some of the unfailed rods showed local diameter increases of up to 5 mils. The failed rod exhibited large diameter increases (up to 20 mils) at the locations of cracks observed on the rods.

Figures $3,4,5$, and 6 show examples of ridging and diameter increases in two unfailed rods and one failed rod.

Selected regions of three of the unfailed rods showing local diameter increases were also profiled in the nonrotating mode to produce linear scans. These scans were made at $30^{\circ}$ intervals. The objective was to determine whether increases were circumferential or localized at one small spot. In all cases, the diameter increases were caused by localized spots spanning no more than $30^{\circ}$ of the rod circumference. The data also showed that the ridges extended uniformly over the fuel rod circumference. Figure 7 shows the appearance of the ridges and diameter increases in rod 157E01.

Batch 7 rods showed slightly larger ovalities in the midregion ( 1 mil vs 0.5 mil) compared to the batch 8 rods. Clad ridging was also less prominent. The extent of clad creepdown in batch 7 rods also appeared to be slightly larger than in batch 8 rods. Figure 8 shows typical ridging and ovality and a region of local diameter increase observed in one of the batch 7 rods. Figure 9 shows the appearance of typical full length profile traces obtained on a batch 8 and a batch 7 fuel rod. Differences in the degree of ovality, ridging, and creepdown are clearly seen. 


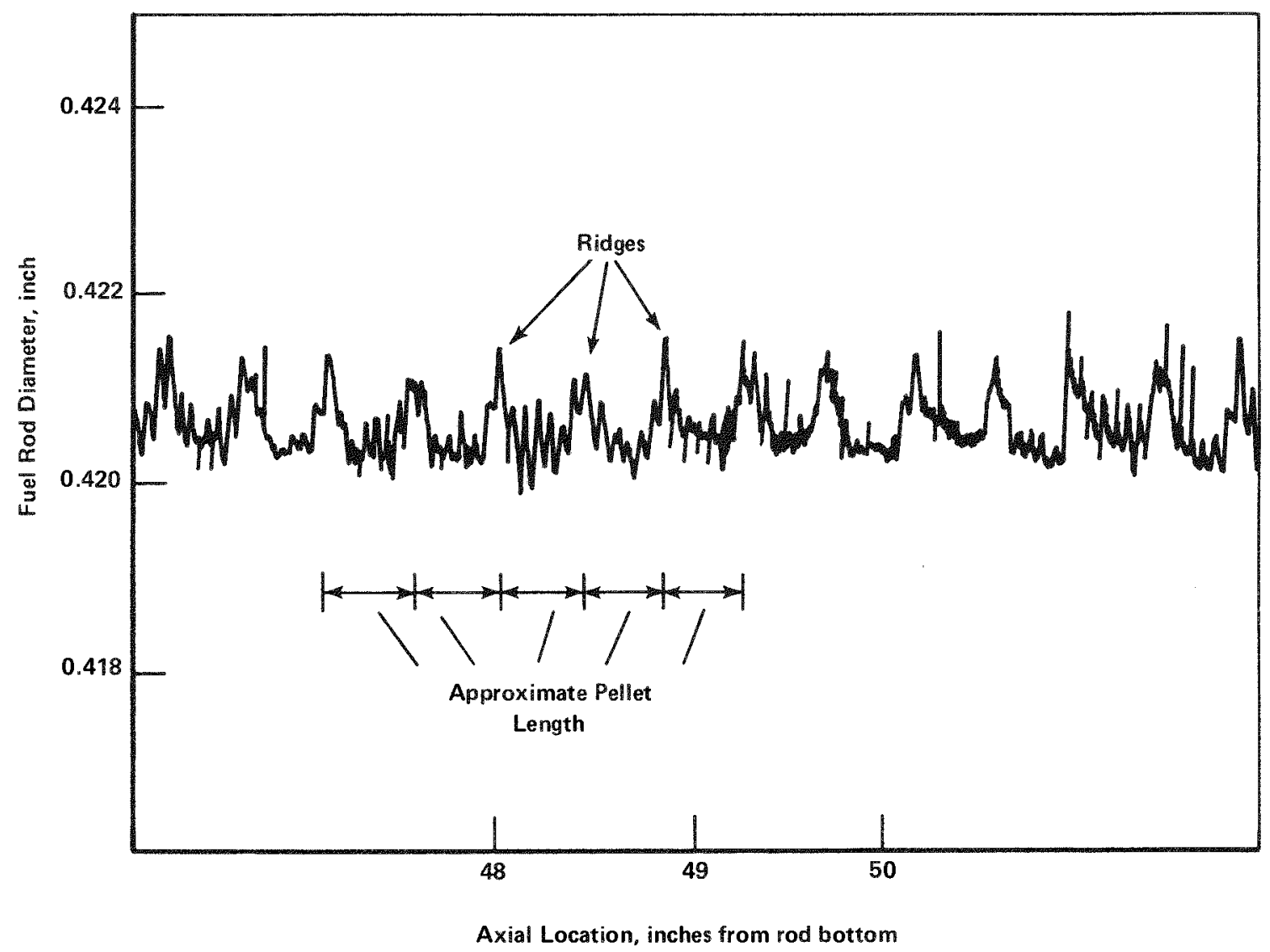

FIGURE 3. Profilometer Scan Showing Typical Ridging Observed In The Unfailed Batch 8 Rod 062E12 


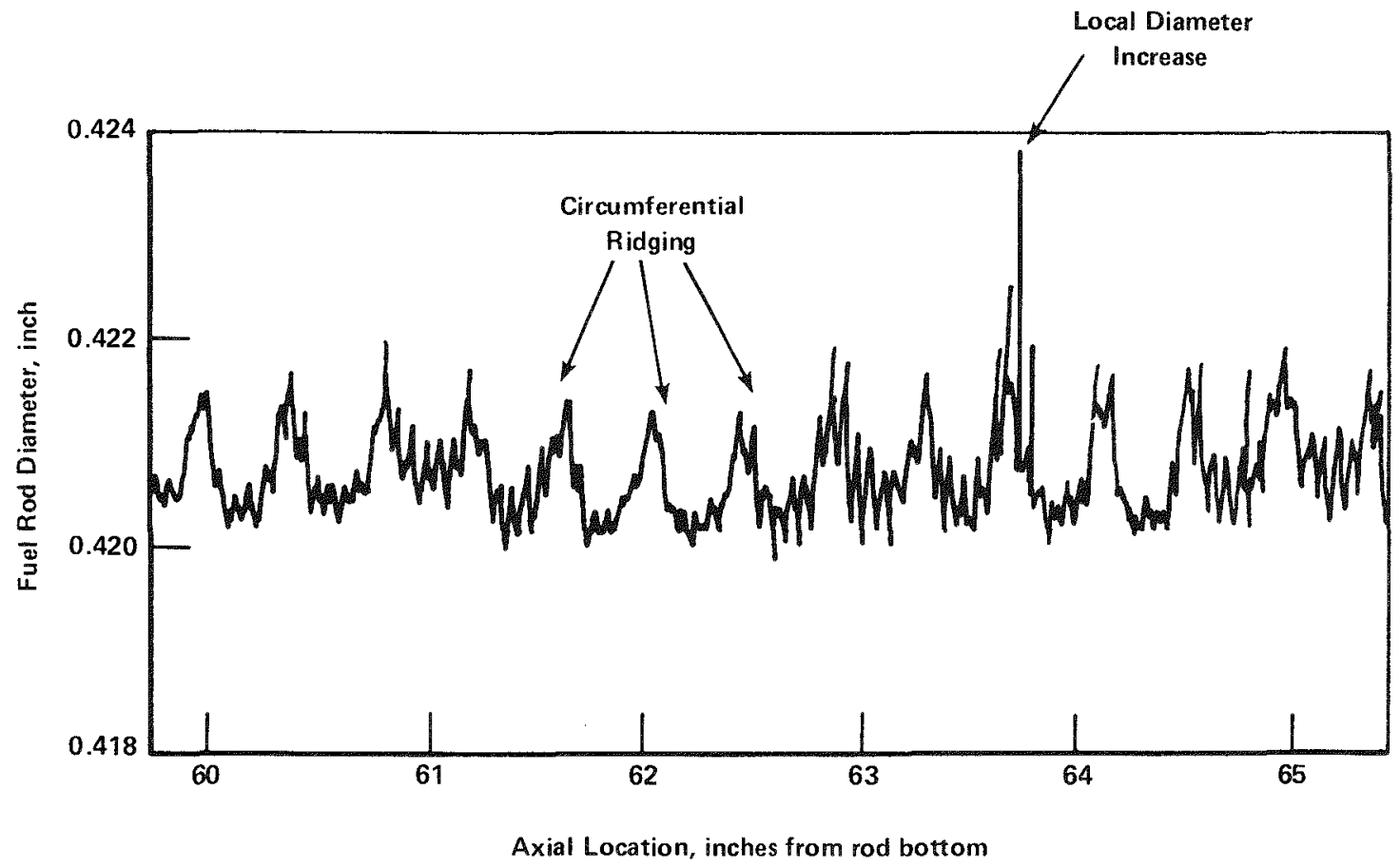

FIGURE 4. Small Diameter Increase Observed At 63-3/4 in. From Rod Bottom In The Unfailed Batch 8 Rod 157E01 


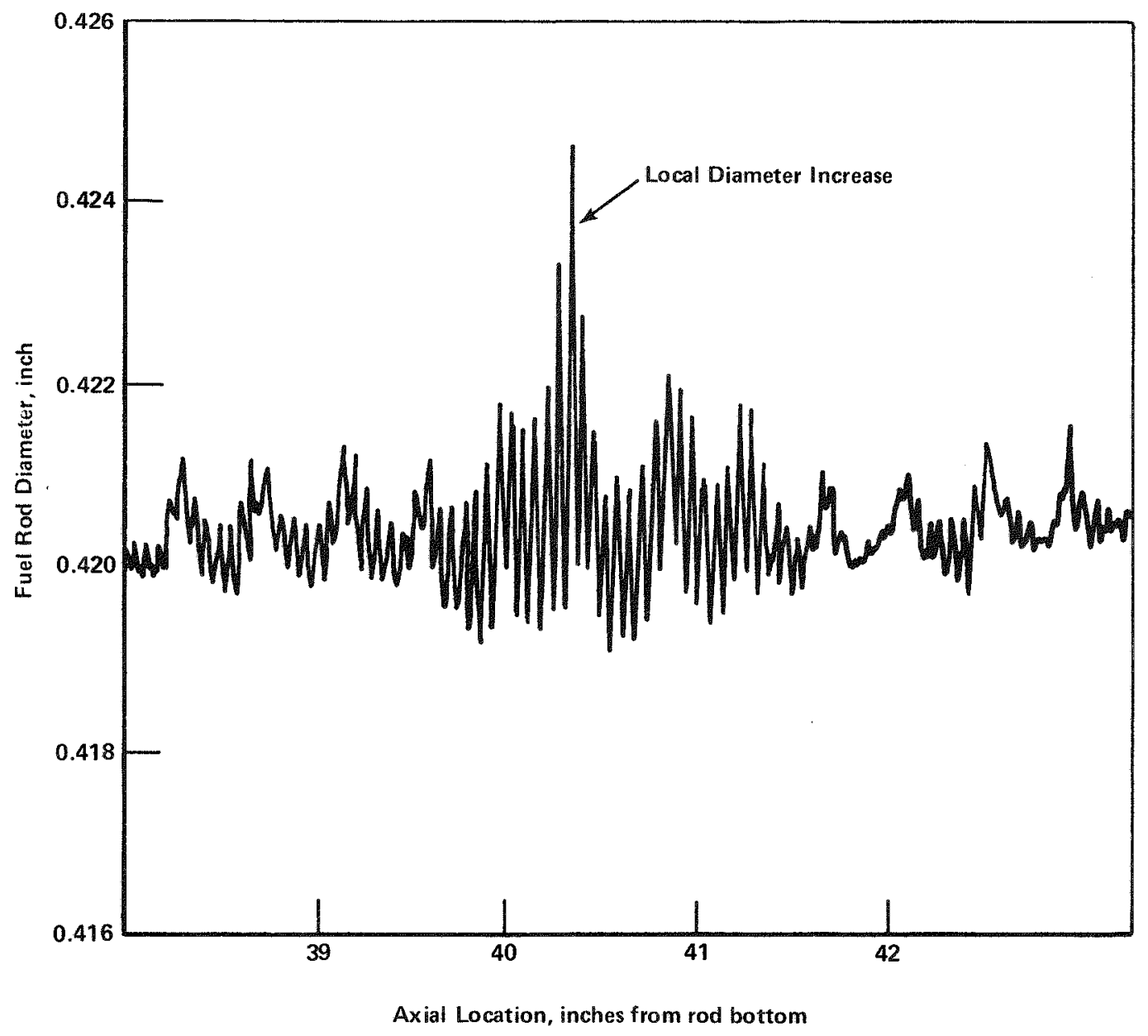

FIGURE 5. Local Diameter And Ovality Increase Observed In Unfailed Batch 8 Rod $062 E 12$ 


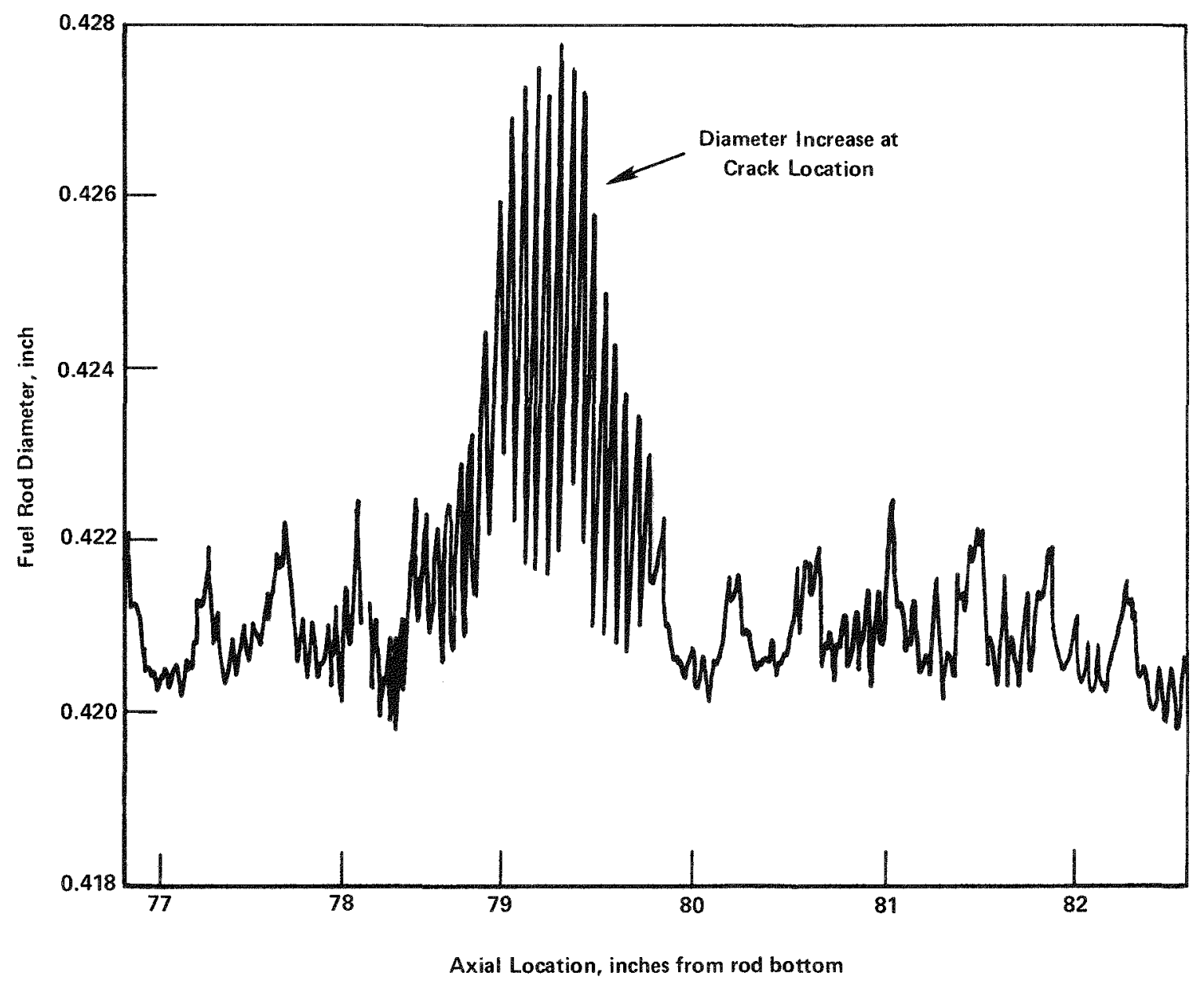

FIGURE 6. Diameter Increase At The Location Of Tight Axial Crack Observed In The Failed Batch 8 Rod $013 E 03$ 


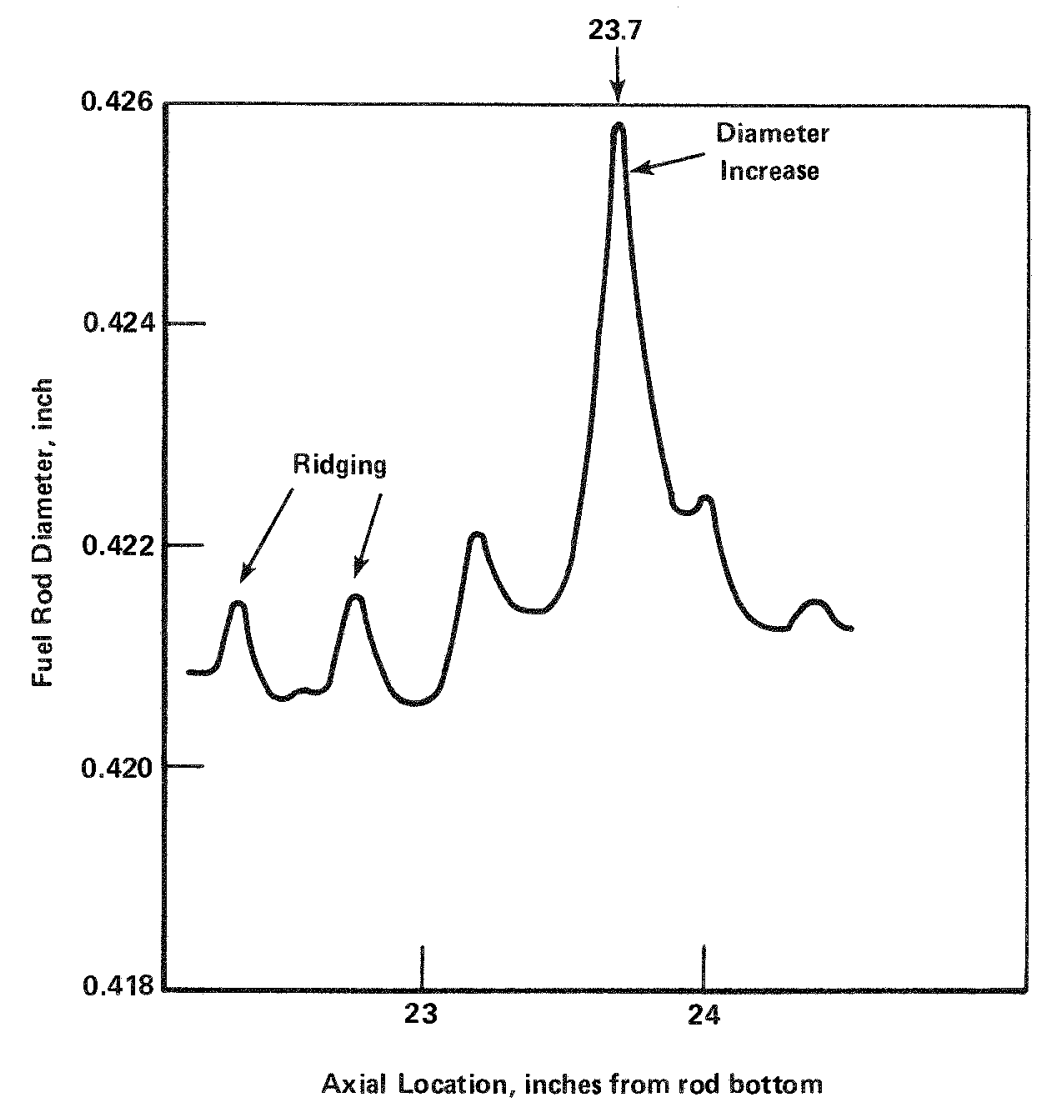

FIGURE 7. Examples Of Ridging And Diameter Increase Observed In Unfailed Batch 8 Rod 157E01 By Linear Profilometry Scan 


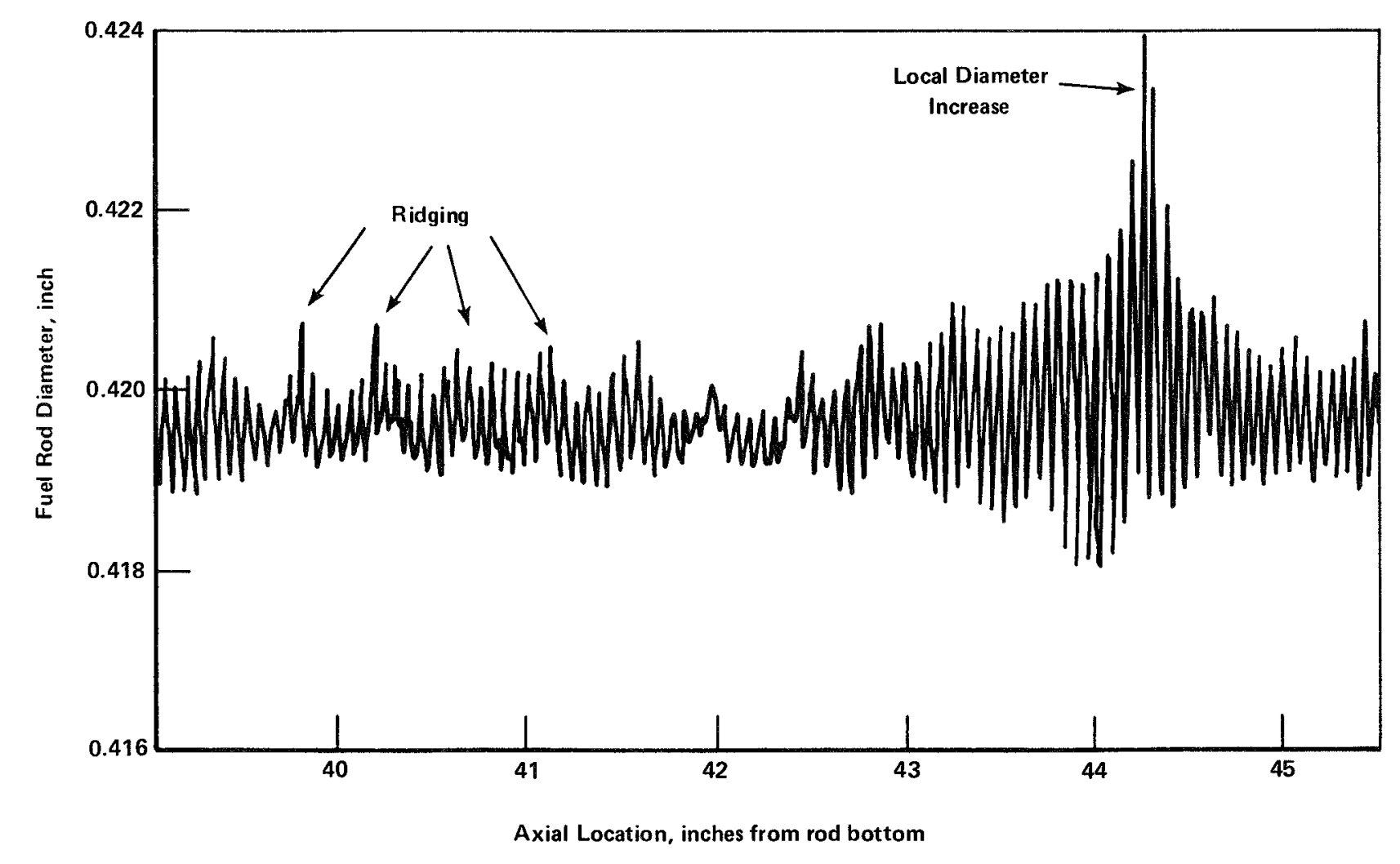

FIGURE 8. Example Of Ovality And Ridging And Local Diameter Increase Observed In The Unfailed Batch 7 Rod 595A 10 
atch 8 Rod 157E01

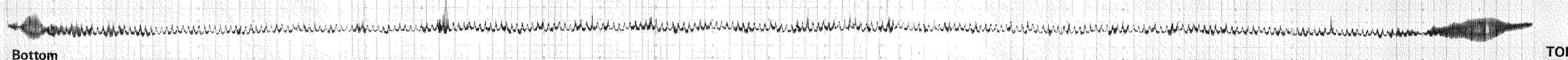

Bottom

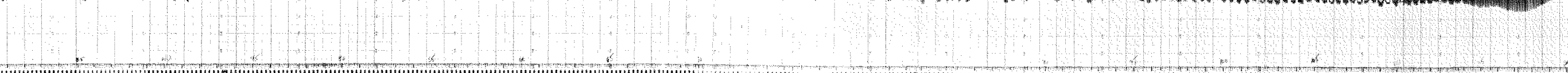

Batch 7 Rod 595A12

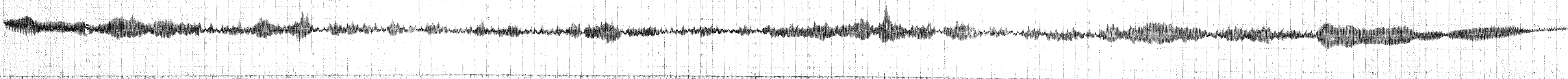

FIGURE 9. Full Length Spiral Profilometry Chart Obtained On Batch 8 Rod $157 E 01$ And
Batch 7 Rod 595 A12 


\subsubsection{Eddy Current Scans}

Results of encircling coil scans showed that the eddy current system was highly responsive to the clad ridging. In addition to the ridge signals, a number of defect indications were observed. The locations of these indications coincided with those of fuel rod diameter increases observed by profilometry. Figure 10 shows a typical example of an eddy current indication at the location of diameter increases.

Selected regions of several fuel rods were also scanned using the probe coil eddy current system. These regions had shown one or more defect indications in the encircling coil scans.

Results from probe coil scans showed much stronger indications at the same location than did encircling coil scans. The indications were also found to be localized (i.e., restricted to a small fraction of the fuel rod circumference). This observation confirms those from the profilometry scans. Eddy current scan results on batch 7 rods were very similar to those on batch 8 rods but showed fewer indications.

\subsubsection{Gamma Scans}

Selected unfailed and failed fuel rods were gamma scanned over the length of the fuel stack. The rods were scanned for both gross gamma and Cs137 activity profiles. Batch 8 rods in general showed no anomalies. Activity depressions at pellet interfaces were clearly observed, indicating little or no pellet dish filling or axial redistribution of fission products. In the failed fuel rod, small reductions in activity were observed at the locations of cracks, as shown in Figure 11. This was presumably due to the leaching of fuel out of the rod.

Gamma scan results on the batch 7 high burnup rods showed somewhat different characteristics compared to the batch 8 fuel rods. The scans in general were "noisier" and the midregion of the rod showed no discernible activity depressions at pellet interfaces, as shown in Figure 12. This result suggests that the dishes in the fuel pellets of batch 7 rods had closed during operation. Data from metallography (presented later) showed that the dishes contained pieces of fuel and there was no apparent change in the dish profile from the as-fabricated condition.

Gamma scan results from the lower burnup batch 7 rod 595A1 showed no anomalies. 

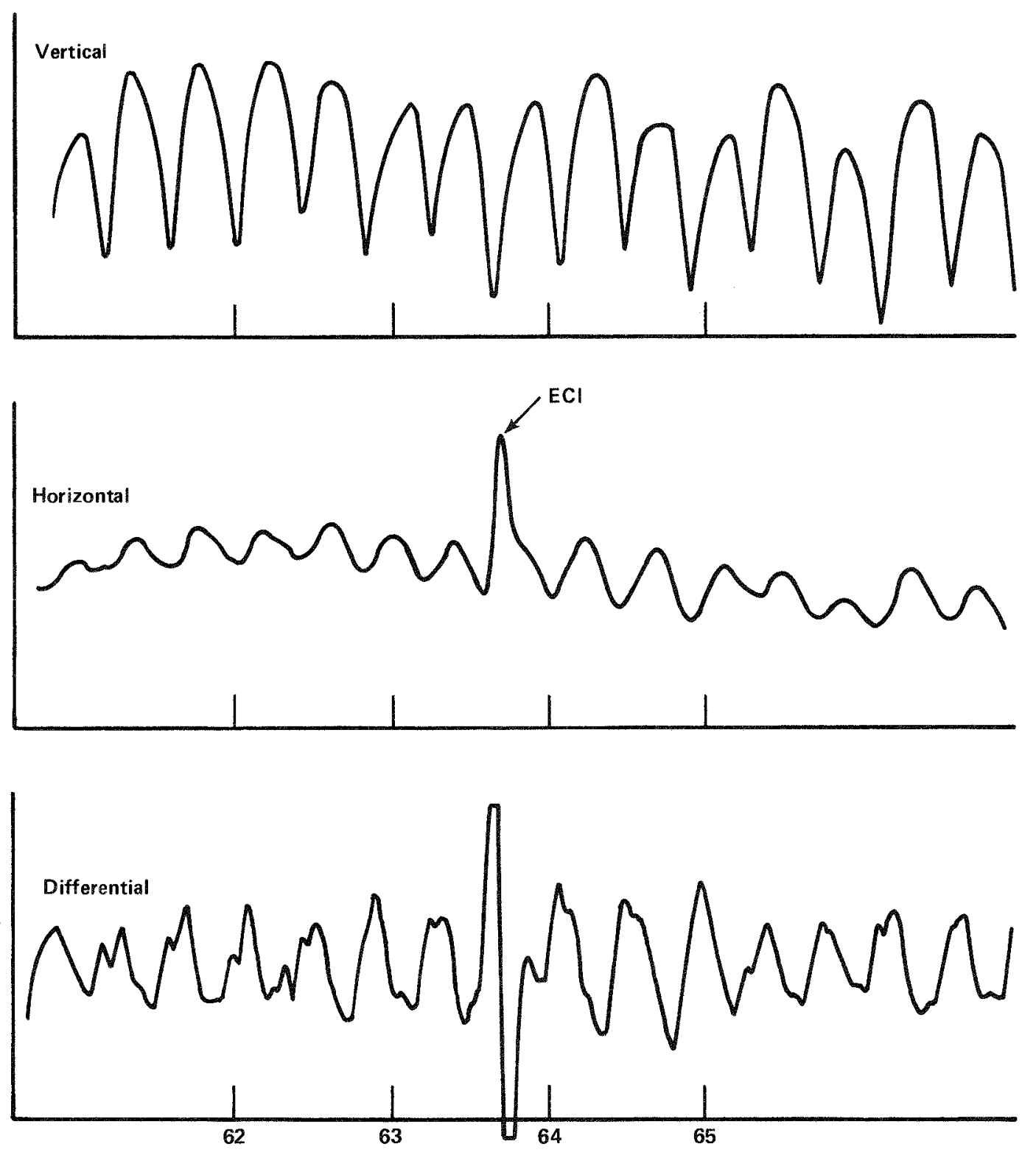

FIGURE 10. Eddy Current Indication At The Location Of Diameter Increase Observed In The Unfailed Batch 8 Rod 157E01 


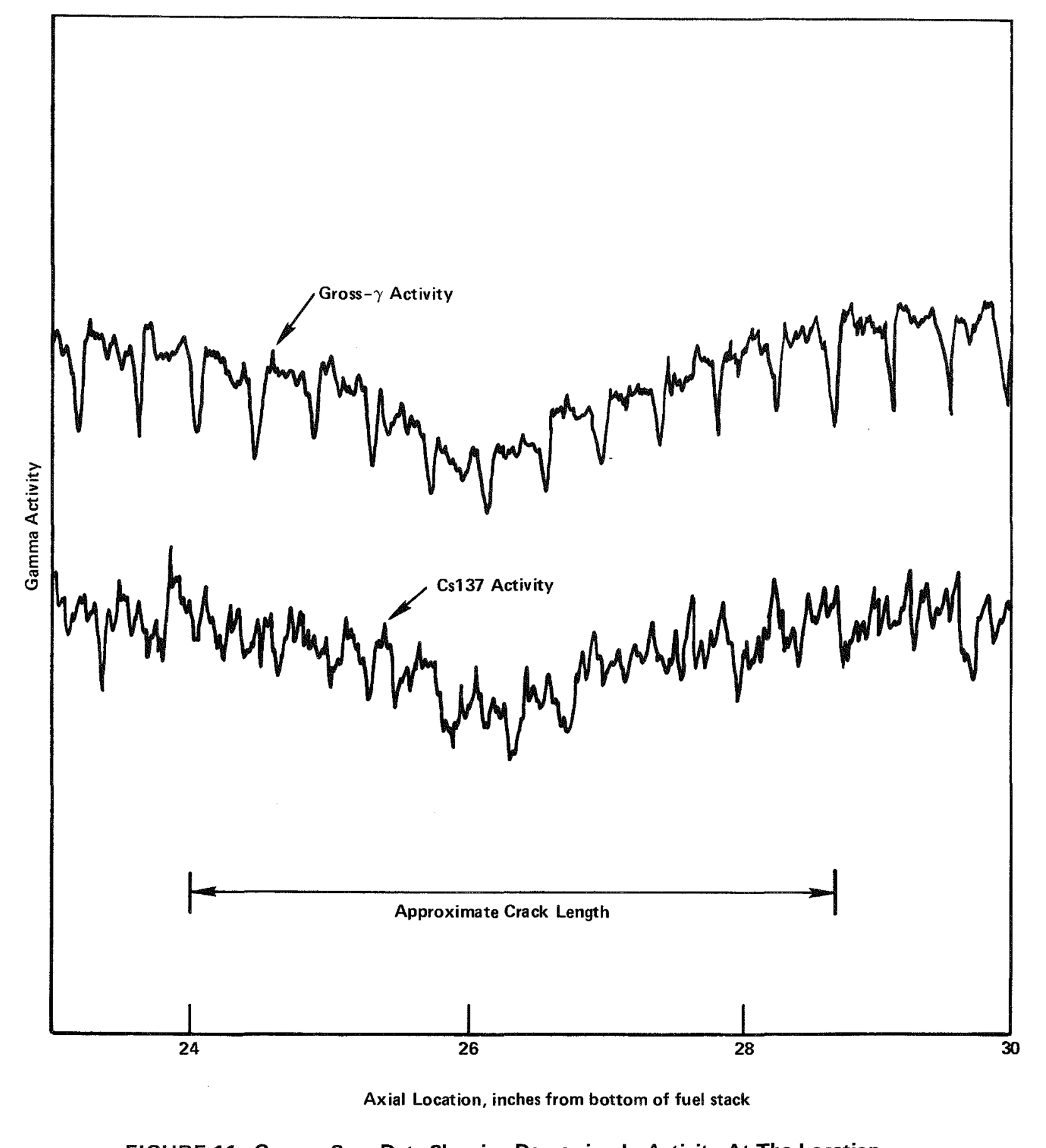

FIGURE 11. Gamma Scan Data Showing Depression In Activity At The Location Of The Cladding Crack In The Failed Batch 8 Rod $013 E 03$ 


\section{Batch 7 Rod 595A12}

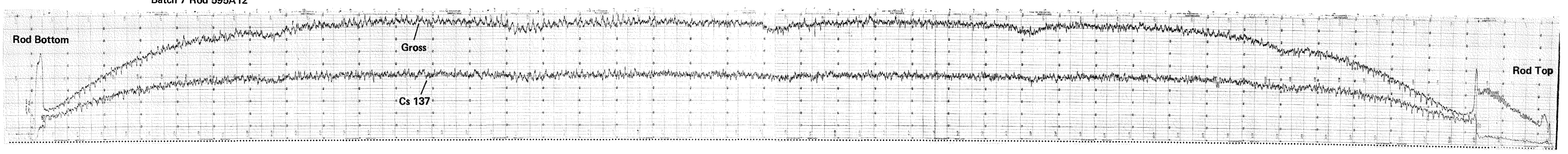

\section{Batch 8 Rod 157E01}

Rod Botom

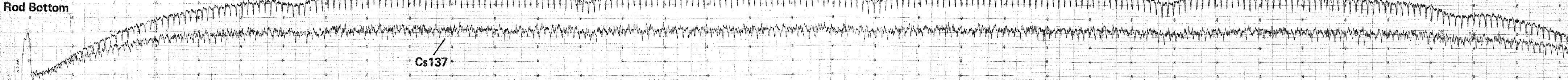

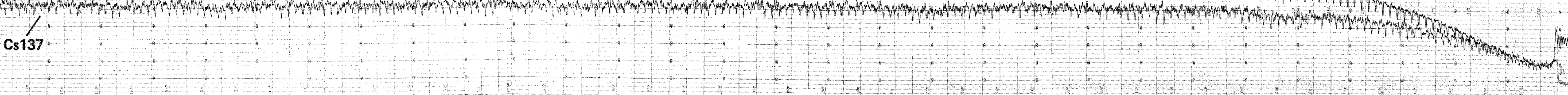




\subsubsection{Visual Examinations}

Selected batch 8 rods were examined using a stereovisual system, with emphasis on regions where anomalies had been identified by other NDE data. In two of the unfailed fuel rods, visible "bumps" were observed at the locations of diameter increases and eddy current indications. Figures 13 and 14 show the appearance of these bumps in two of the rods.

The unfailed rods, in general, appeared to be in excellent condition, with very little crud present. Crud decoration of the ridging on the cladding could, however, be readily seen.

Only one of the failed rods was visually examined in detail. This rod had been previously identified as having a single crack which probably resulted from a primary defect. Upon closer examination in the hot cell, a second crack was observed approximately 50 inches from the other crack. The two cracks appeared to be unrelated to each other. The locations of these cracks corresponded to the locations of anomalies observed in other NDE data. Figures 15 and 16 show the appearance of the two cracks in this rod.

\subsubsection{Summary of NDE Results}

Table 6 summarizes the results from all the nondestructive examinations performed on the rods. The data show highly consistent results from the different NDE procedures, with good correlation of locations of the anomalies. Examination of all the data together also provides a sound basis for selecting rods and rod sections for destructive examination.

\subsection{FUEL ROD DESTRUCTIVE EXAMINATIONS}

The primary objectives of the destructive examinations were to locate incipient cracks that served as the first step in the clad failure process, to characterize those cracks, and to determine the mechanism of failure. These objectives were to be accomplished by metallographic examinations. The other important objective of the destructive examinations was to provide background information on general fuel rod performance.

The destructive examinations performed on the selected rods consisted of:

(1) Fuel rod puncture for fission gas collection and fuel rod internal volume measurement

(2) Fuel-clad metal lography 


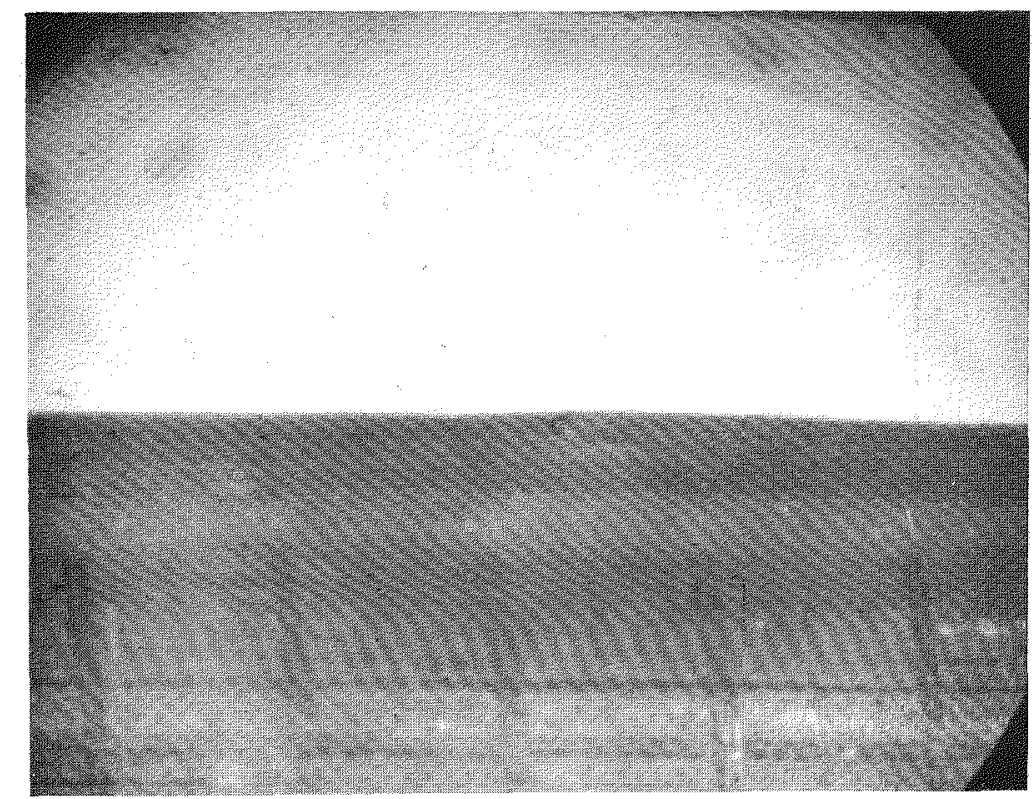

$\sim 8 X^{*}$

FIGURE 13. Photograph Showing A "Bump" On Unfailed Batch 8 Rod 157E01

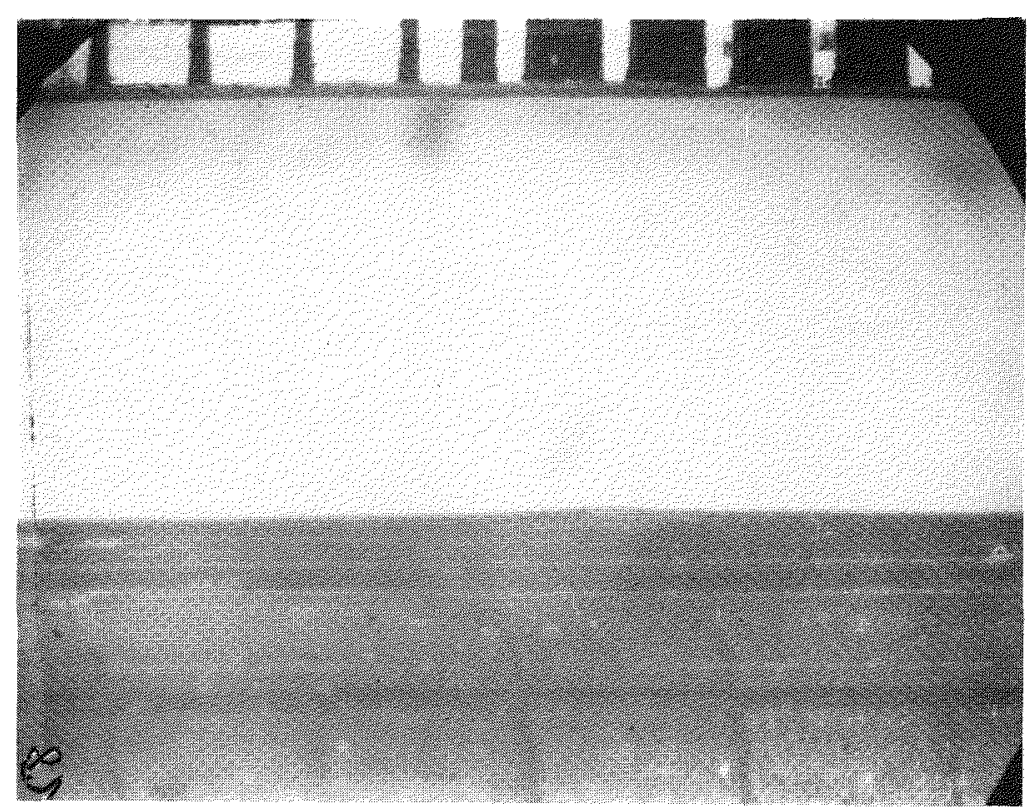

$\sim 8 X^{*}$

FIGURE 14. Photograph Showing A "Bump" In Unfailed Batch 8 Rod 217E02 At 35 Inches From Rod Bottom

*Please note that the illustration(s) on this page have been reduced $10 \%$ in printing. 


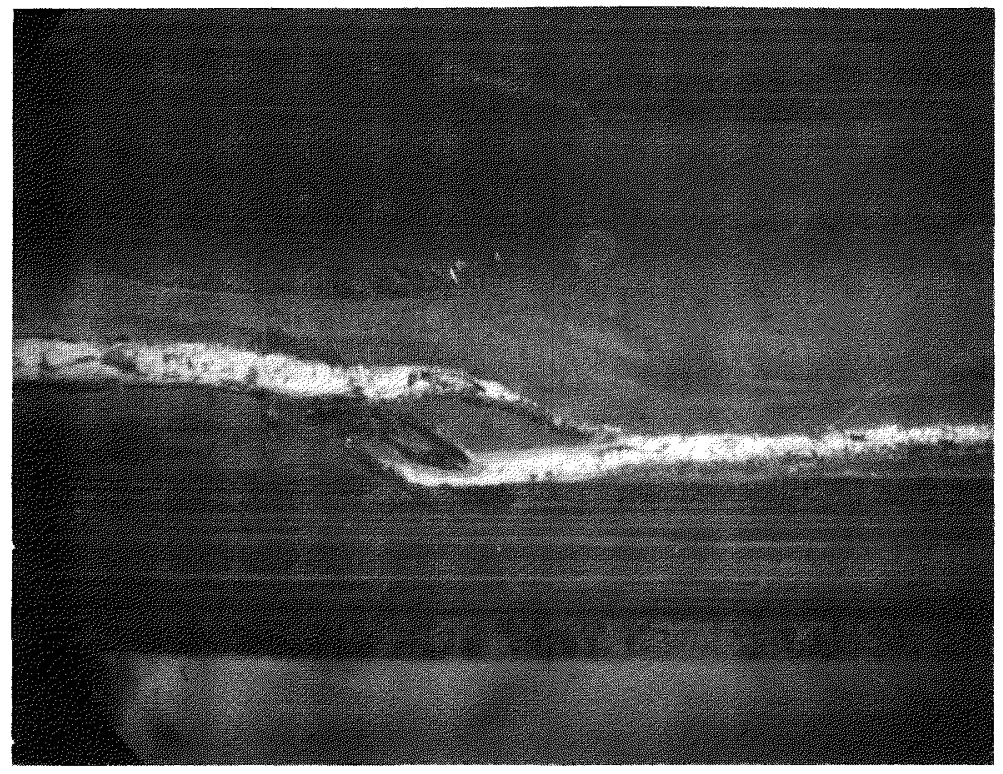

$\sim 8 X^{*}$

FIGURE 15. Appearance Of The Longer Of The Two Cracks Observed In Failed Rod $013 E 03$ At $\sim 25$ Inches From Rod Bottom

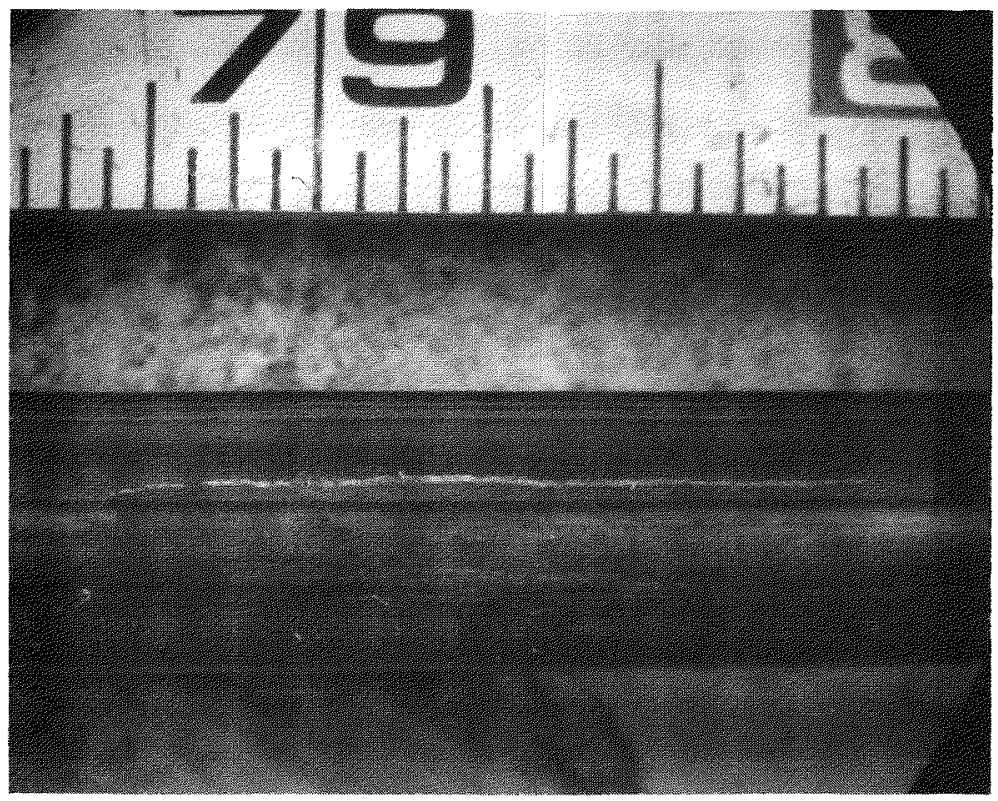

$\sim 8 X^{*}$

FIGURE 16. Appearance Of The Tight Crack In Rod 013E03 At 79 Inches From Rod Bottom

* Please note that the illustration(s) on this page have been reduced $10 \%$ in printing. 
TABLE 6

SUMMARY OF NDE DATA

\begin{tabular}{|c|c|c|c|c|c|c|}
\hline \multirow[b]{2}{*}{ Rod No. } & \multirow[b]{2}{*}{ Profilometry Data } & \multicolumn{2}{|c|}{ Eddy Current $^{\prime b !}$} & \multirow[b]{2}{*}{ Gamma Scan } & \multirow[b]{2}{*}{ Visual Exam } & \multirow[b]{2}{*}{ Status } \\
\hline & & Encircling & Probe & & & \\
\hline \multicolumn{7}{|c|}{ Fuel Assembly HO7 } \\
\hline $\begin{array}{r}\text { 013-EO3 } \\
\text { A1 } \\
\text { Failed rod }\end{array}$ & $\begin{array}{l}\text { Split at } 25-29^{\text {.'al }} \\
\sim 15 \text { mil diam increase } \\
\text { Crack at } 78-80^{\prime \prime} \\
\sim 4 \text { mil diam increase } \\
\text { Heavily ridged } \\
\sim 1.0 \text { mil creep down }\end{array}$ & $\begin{array}{l}\mathrm{ECl} \text { at } 25-29^{\prime \prime} \\
\mathrm{ECl} \text { at } 78-80^{\prime \prime}\end{array}$ & NP & $\begin{array}{l}\text { Small depression at } 25-27^{\prime \prime} \\
(\sim 15 \% \text { lower activity) } \\
\text { Another small depression at } \\
78-78.5^{\prime \prime} \\
(\sim 8 \% \text { lower activity) }\end{array}$ & $\begin{array}{l}\text { Split at } 25-29^{\prime \prime} \\
\text { Crack at } 78.5-80^{\prime \prime}\end{array}$ & in storage \\
\hline $\begin{array}{r}\text { O13-EO6 } \\
\text { F4 }\end{array}$ & $\begin{array}{l}\text { Small ovality and } \\
\text { diam incrase at } 43-1 / 2^{\prime \prime}, \\
85^{\prime \prime} \\
\text { Ridging } \\
\text { Creep down } \sim 1.0 \mathrm{mil}\end{array}$ & $\begin{array}{l}\mathrm{ECl}-\text { at } 32-1 / 4^{\prime \prime} \\
47-1 / 4^{\prime \prime} \\
\text { All ECl weak }\end{array}$ & NP & NP & NP & $\begin{array}{l}\text { Returned to } \\
\text { assembly }\end{array}$ \\
\hline $\begin{array}{r}217-\mathrm{EO} 2 \\
\mathrm{~J} 12\end{array}$ & $\begin{array}{l}\text { Ridging } \\
\sim 3 \text { mil bump at } 23-5 / 8^{\prime \prime} \\
\sim 1.2 \text { mil creep down } \\
\sim 4 \text { mil Bump } 30-45^{\circ} \text { span }\end{array}$ & $\begin{array}{l}\text { Strong } \mathrm{ECl} \text { at } \\
23-7 / 8^{\prime \prime} \\
\mathrm{ECl} \text { at } 40,63-1 / 4^{\prime \prime} \\
80-1 / 2^{\prime \prime-} \text {-weak } \\
\text { to medium }\end{array}$ & $\begin{array}{l}\text { Strong ECl } \\
315-0^{\circ}\end{array}$ & No anomalies & $\begin{array}{l}\text { Visible bump at } \\
23-3 / 4^{\prime \prime}\end{array}$ & $\begin{array}{l}\text { Destructively } \\
\text { examined }\end{array}$ \\
\hline $\begin{array}{r}\text { 157-EO1 } \\
\text { M12 }\end{array}$ & $\begin{array}{l}\text { Ridging } \\
\text { Diam ovality increase } \\
\text { at } 35-1 / 2^{\prime \prime}, \text { small bumps } \\
\text { at } 47^{\prime \prime}, 51-1 / 2^{\prime \prime} \\
\text { Med bump at } 63-3 / 4^{\prime \prime} \\
\text { local bumps of } 5 \text { mils }\end{array}$ & $\begin{array}{l}\text { Strong } \mathrm{ECl} \text { at } 35-1 / 2^{\prime} \\
63-3 / 4^{\prime \prime}\end{array}$ & $\begin{array}{l}\text { "Strong ECl } \\
135-180^{\circ} \\
\text { Weak ECl at } 95-3 / 4 " \\
47-51^{\prime \prime} \\
270^{\circ} \text { at } 63-3 / 4 "\end{array}$ & $\begin{array}{l}\text { No anomalies } \\
\text { at } 35-1 / 2^{\prime \prime}\end{array}$ & $\begin{array}{l}\text { Visible bumps at } \\
35-3 / 8^{\prime \prime}-63-3 / 4 "\end{array}$ & $\begin{array}{l}\text { Destructively } \\
\text { examined }\end{array}$ \\
\hline $\begin{array}{r}\text { O62-E12 } \\
\text { L8 }\end{array}$ & $\begin{array}{l}\text { Ovality change } 35.5^{\prime \prime} \\
\text { Diam \& oval increase at } \\
40-1 / 2^{\prime \prime} \\
\text { Ovality change at } 85^{\prime \prime}\end{array}$ & Strong $\mathrm{ECl}$ at $40-1 / 2^{\prime}$ & $\begin{array}{l}\text { "Strong } E C l \\
270^{\circ} \text { at } 40-1 / 2 " \\
E C l \text { at } 35-1 / 2^{\prime \prime} \\
180-270^{\circ}\end{array}$ & No anomalies & $\begin{array}{l}\text { Possible bumps at } \\
35-1 / 2^{\prime \prime}, 40-1 / 2^{\prime \prime}\end{array}$ & $\begin{array}{l}\text { Rod punctured } \\
\text { In storage }\end{array}$ \\
\hline
\end{tabular}

(a) All locations from bottom of rod.

(b) $\mathrm{ECl}=$ Eddy current indication.

NP = Not performed 
TABLE 6 (Continued)

\begin{tabular}{|c|c|c|c|c|c|c|}
\hline \multirow[b]{2}{*}{ Rod No. } & \multirow[b]{2}{*}{ Profilometry Data } & \multicolumn{2}{|c|}{ Eddy Current ${ }^{(b)}$} & \multirow[b]{2}{*}{ Gamma Scan } & \multirow[b]{2}{*}{ Visual Exam } & \multirow[b]{2}{*}{ Status } \\
\hline & & Encircling & Probe & & & \\
\hline $\begin{array}{r}\text { 010-EO3 } \\
\text { L12 }\end{array}$ & $\begin{array}{l}\text { Diam increase at } 17^{\prime \prime}, 26^{\prime \prime}, 32^{\prime \prime} \\
48-1 / 2^{\prime \prime}, 78-1 / 2^{\prime \prime}, 82^{\prime \prime} \\
\text { Ridging }\end{array}$ & Weak indications & $\begin{array}{l}\text { Ridge type } \\
\text { indication at } \\
17^{\prime \prime}, 32^{\prime \prime} \mathrm{ECl} \\
\text { at } 26^{\prime \prime} 48-1 / 2^{\prime \prime} \\
51-1 / 2^{\prime \prime}, 53^{\prime \prime} \\
56^{\prime \prime}, 57^{\prime \prime}, 102- \\
1 / 4^{\prime \prime}, 84^{\prime \prime}, 86^{\prime \prime}\end{array}$ & NP & $N P$ & $\begin{array}{l}\text { Returned to } \\
\text { assembly }\end{array}$ \\
\hline $\begin{array}{r}1007-E 1 \\
\text { E4 }\end{array}$ & $\begin{array}{l}\text { Ridging } \\
\text { Ovality change at } 78^{\prime \prime}, 110-1 / 2^{\prime \prime}\end{array}$ & $\begin{array}{l}\text { Few weak } \\
\text { indications }\end{array}$ & $\mathrm{NP}$ & NP & NP & In storage \\
\hline $\begin{array}{r}\text { O65-E11 } \\
\text { G4 }\end{array}$ & $\begin{array}{l}\text { Ridging } \\
\text { Ovality change at } 11-1 / 2^{\prime \prime}, 61 \text { - } \\
1 / 2^{\prime \prime}, 88^{\prime \prime}\end{array}$ & NP & NP & NP & NP & $\begin{array}{l}\text { Returned to } \\
\text { assembly }\end{array}$ \\
\hline $\begin{array}{r}\text { O75-EO5 } \\
\text { K12 }\end{array}$ & $\begin{array}{l}\text { Ridging } \\
\text { Small diam increase } 37-1 / 2^{\prime \prime} \\
47^{\prime \prime}, 67^{\prime \prime}, 85-1 / 2^{\prime \prime}, 97^{\prime \prime}\end{array}$ & $\begin{array}{l}\text { Many weak } \\
\text { indications }\end{array}$ & NP & NP & NP & $\begin{array}{l}\text { Returned to } \\
\text { assembly }\end{array}$ \\
\hline \multicolumn{7}{|c|}{ Fuel Assembly G11 } \\
\hline $\begin{array}{r}\text { 595-A12 } \\
\text { F11 }\end{array}$ & $\begin{array}{l}\text { Larger ovality than } \mathrm{HO} \text { rods } \\
\text { Ridging diam increase at } 24 \text { - } \\
1 / 2^{\prime \prime}, 38^{\prime \prime}\end{array}$ & $\begin{array}{l}\text { Weak ECl at } \sim 8 \\
\text { ECl at } \sim 42^{\prime \prime}\end{array}$ & NP & $\begin{array}{l}\text { Noisier gross gamma trace than } \\
\text { HO7 rods } \\
\text { Few activity spikes }\end{array}$ & NP & In storage \\
\hline 595-A10 & $\begin{array}{l}\text { Ridging } \\
\text { Larger ovality than } \mathrm{HO} \text { rod } \\
\text { Diam increase at } 44-1 / 4^{\prime \prime}\end{array}$ & $\begin{array}{c}\text { Strong ECl at approx } \\
44^{\prime \prime}\end{array}$ & NP & Same as $595-\mathrm{A} 12$ & NP & $\begin{array}{l}\text { Destructively } \\
\text { examined }\end{array}$ \\
\hline 595-A1 & NP & NP & NP & No anomalies & NP & In storage \\
\hline
\end{tabular}


(3) Scanning electron microscopy

(4) Fuel density measurement.

3.3.1 Fission Gas Collection and Analysis, and Void Volume Measurement

The objectives of performing fission gas collection and analysis were to determine whether the fuel rods were unfailed and to determine the fractional fission gas release during irradiation.

Four fuel rods, three from $\mathrm{H} 07$ and one from G11, were punctured. The released gases were collected and the volumes of release were measured using the BCL Hot Laboratory fission gas collection systen.

Table 7 shows the gas release and void volume data obtained from the four fuel rods. Also shown is the estimated volume of fission gas generated and the fractional fission gas release obtained. Data for the three batch 8 rods agree closely, each with $<1$ percent release. The batch 7 rod, however, showed a higher fractional release, namely 4.41 percent. The fractional releases observed in rods from batches 7 and 8 are believed to be in the range expected in a typical commercial pressurized water reactor fuel rod(6). By comparison, fuel rods from the qualification assembly s004 showed even higher releases. The gas release data from four rods showed release fractions in the range 0.2 to 14.3 percent.

\subsubsection{Metallographic Examination}

3.3.2.1 Identification of Incipient Cracks in Batch 8 Rods. From an evaluation of the NDE data (profilometry, eddy current, and visual examinations) three locations from two of the batch 8 rods were selected for metallographic examinations. These locations were 64 inches and 35-3/4 inches from the bottom of rod 157E01, and 24 inches from the bottom of rod 217E02. All locations had shown eddy current indications at local diameter increases (see Table 6).

Cladding cracks were observed in a 11 three specimens. The cracks were intergranular, initiating on the outer surface. In all three cases the cracks appear to be caused by a fuel chip wedged in the fuel-clad gap. Figure 17 shows the presence of a fuel chip in the gap. Figure 18 is the higher magnification montage of the area showing a large cladding crack. Figure 19 shows the appearance of the large crack as well as a second crack at higher magnification. Figures 20, 21, 22, and 23 show similar results obtained from a second and third sample. 
TABLE 7

FISSION GAS RELEASE AND VOID VOLUME DATA OBTAINED ON A BATCH 7 AND BATCH \& FUEL RODS

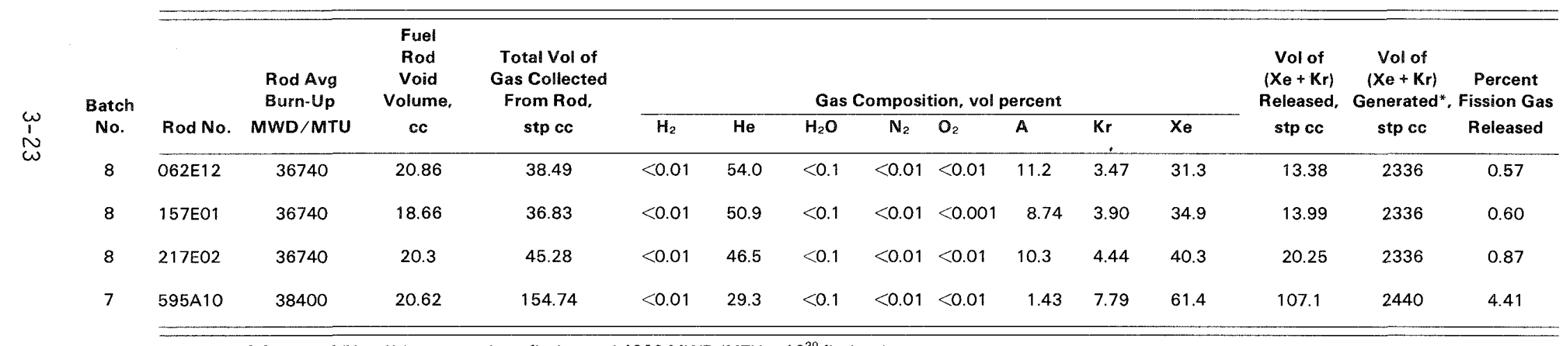

${ }^{*}$ Based on 0.3 atom of $(\mathrm{Xe}+\mathrm{Kr})$ generated per fission and $4000 \mathrm{MWD} / \mathrm{MTU}=10^{20} \mathrm{fission} / \mathrm{cc}$. 


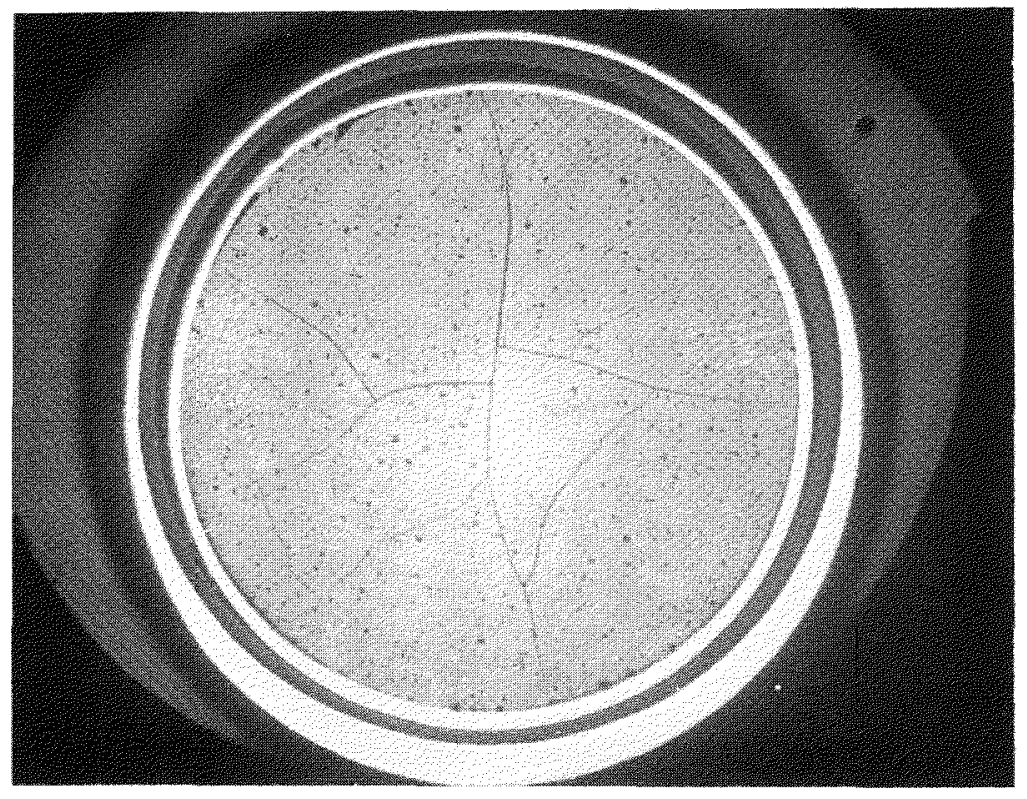

$7 X^{*}$

FIGURE 17. Photomacrograph Showing The Location Of Fuel Pellet-Chip In Batch 8 Rod 157E01 At 64 In. From Rod Bottom

*Please note that the illustration(s) on this page have been reduced $10 \%$ in printing. 


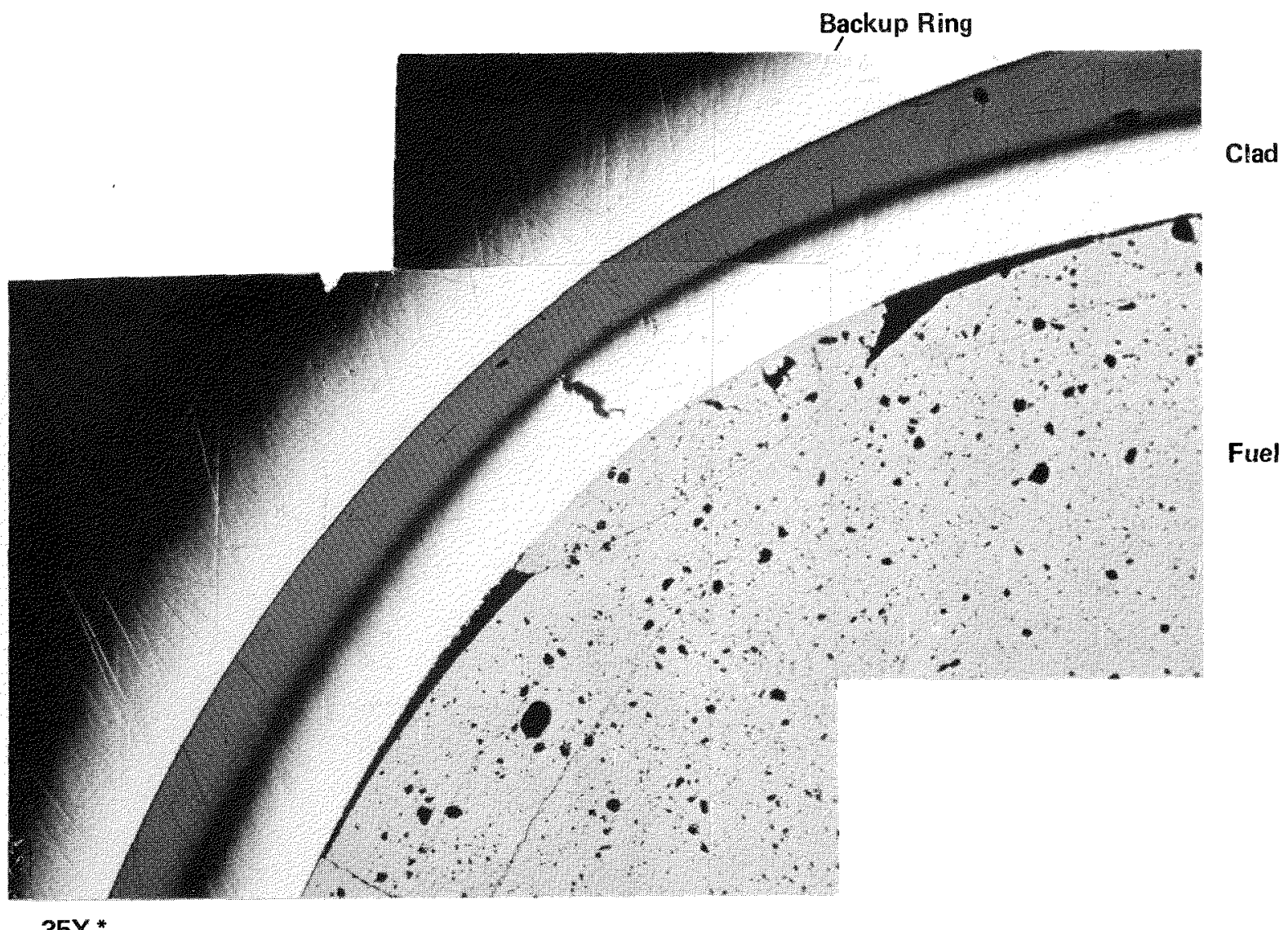

$35 X^{*}$

FIGURE 18. Appearance Of Incipient Cladding Crack In Rod 157E01 64 Inches From Rod Bottom

${ }^{*}$ Please note that the illustration(s) on this page have been reduced $10 \%$ in printing. 


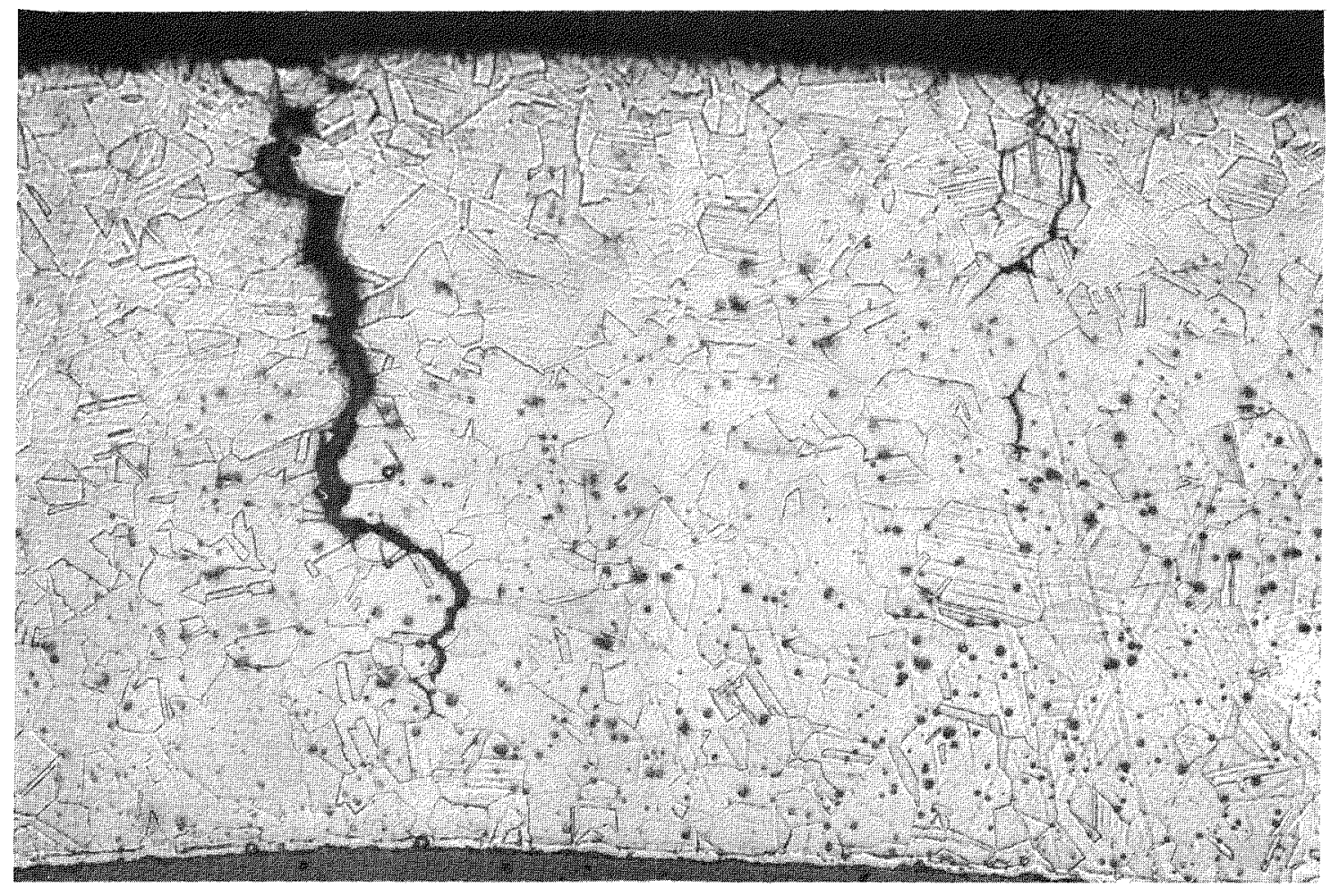

$250 X^{*}$

FIGURE 19. Appearance Of The Two Cracks In Rod 157 E01 At 64 Inches In Etched Condition (Etchant - Glyceregia)

*Please note that the illustration(s) on this page have been reduced $10 \%$ in printing. 


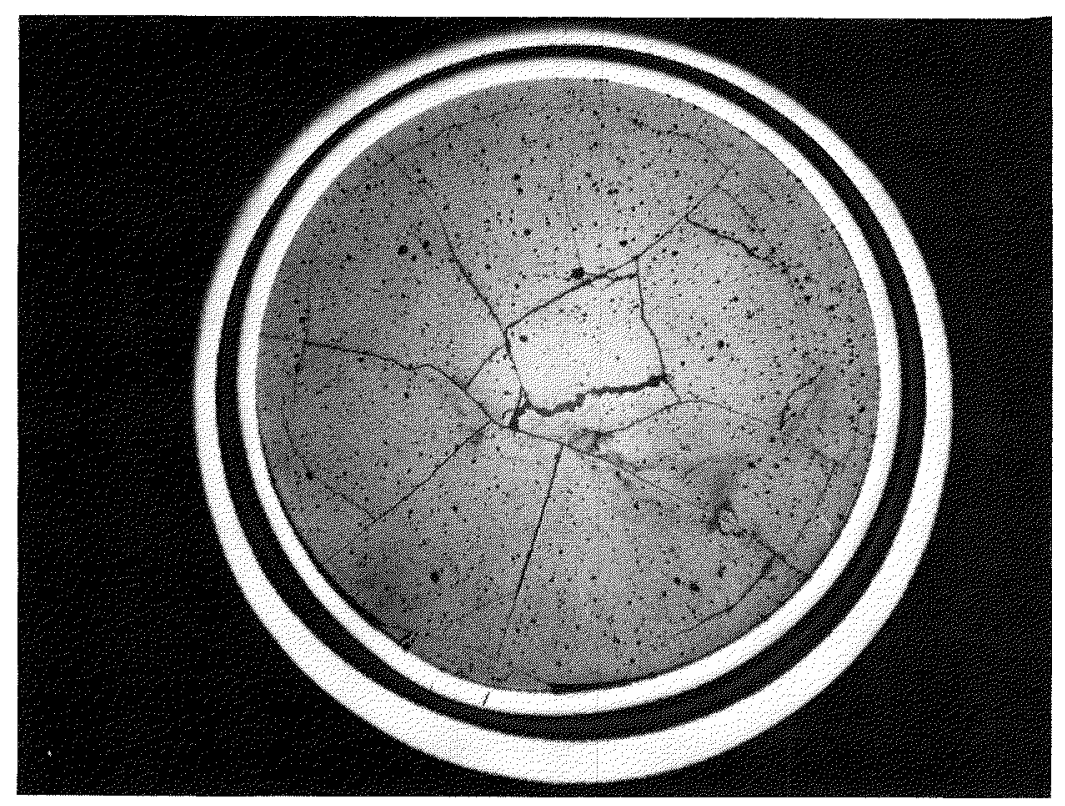

$7 X^{*}$

FIGURE 20. Photomacrograph Of Fuel Chip And Cladding

Crack Observed In Batch 8 Fuel Rod 217E02

*Please note that the illustration(s) on this page have been reduced $10 \%$ in printing. 


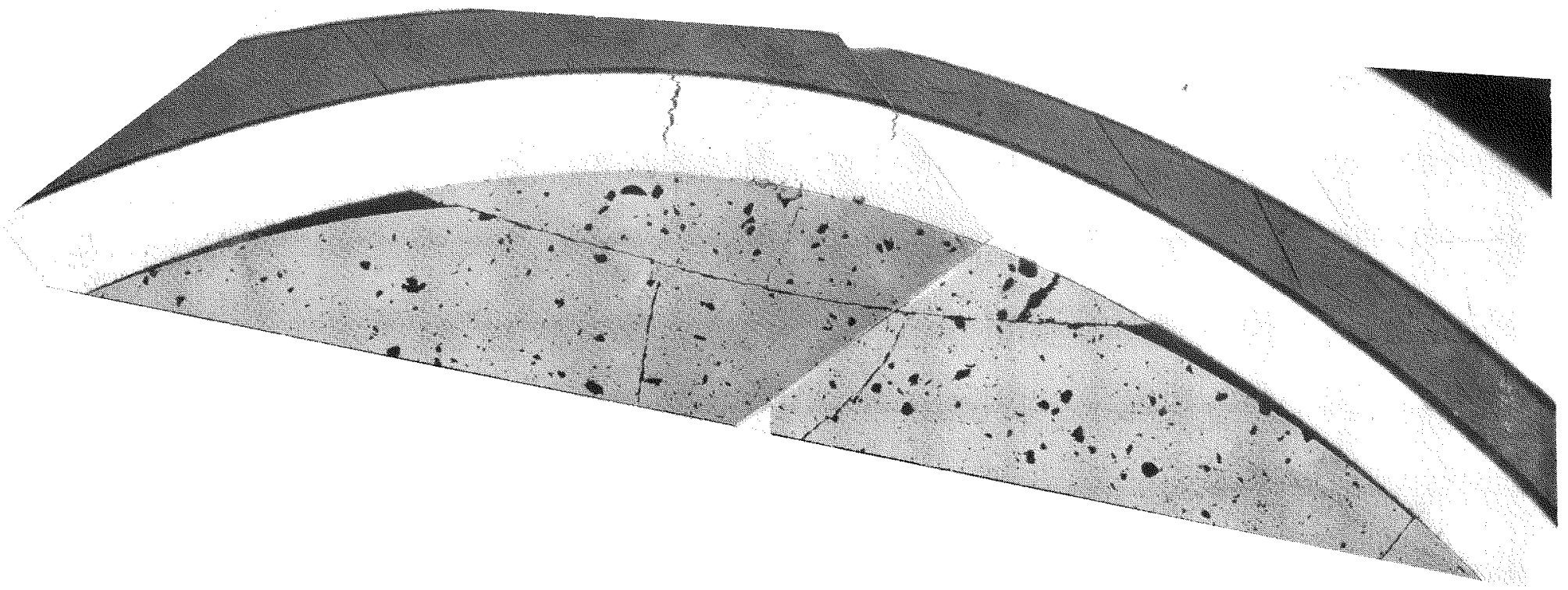

$35 x^{*}$

FIGURE 21. Photo Montage Of Incipient Cladding Crack In Rod 217 E02 At 24 Inches From Rod Bottom

${ }^{*}$ Please note that the illustration(s) on this page have been reduced $10 \%$ in printing. 


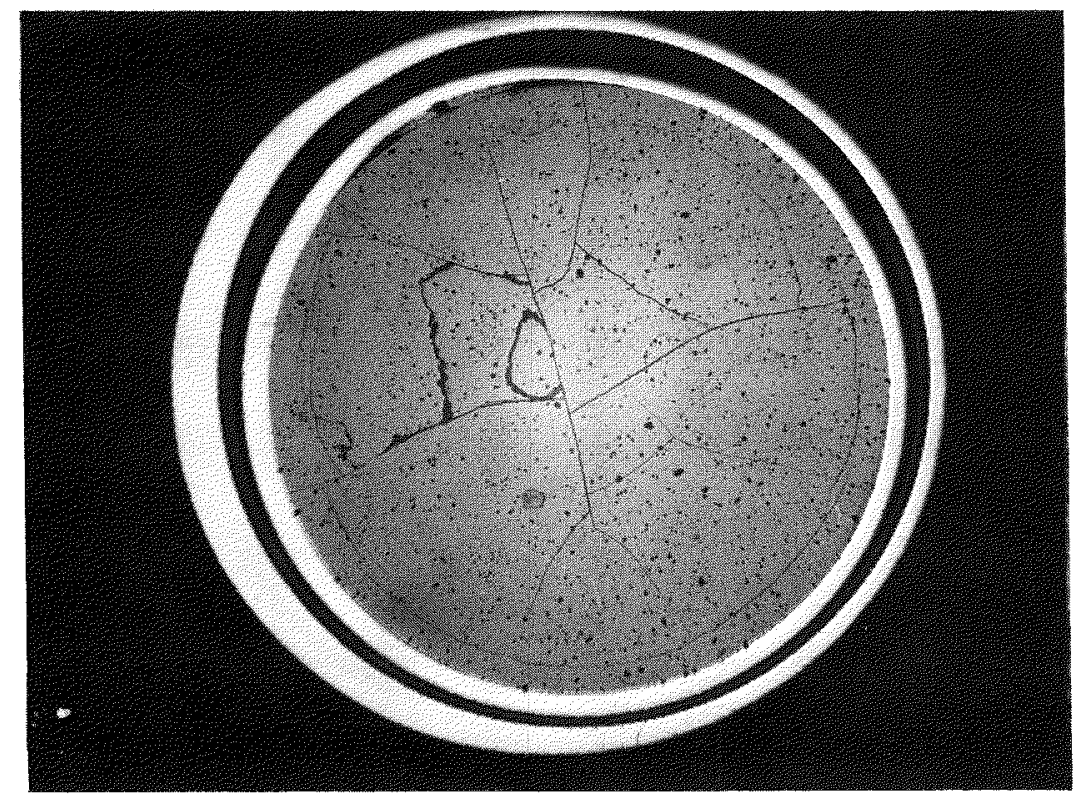

$7 X^{*}$

FIGURE 22. Photomacrograph Showing The Location Of Fuel Chip In The Unfailed Batch 8 Rod 157 E01 At $\sim 35-3 / 4$ Inches From Rod Bottom

${ }^{\star}$ Please note that the illustration(s) on this page have been reduced $10 \%$ in printing. 


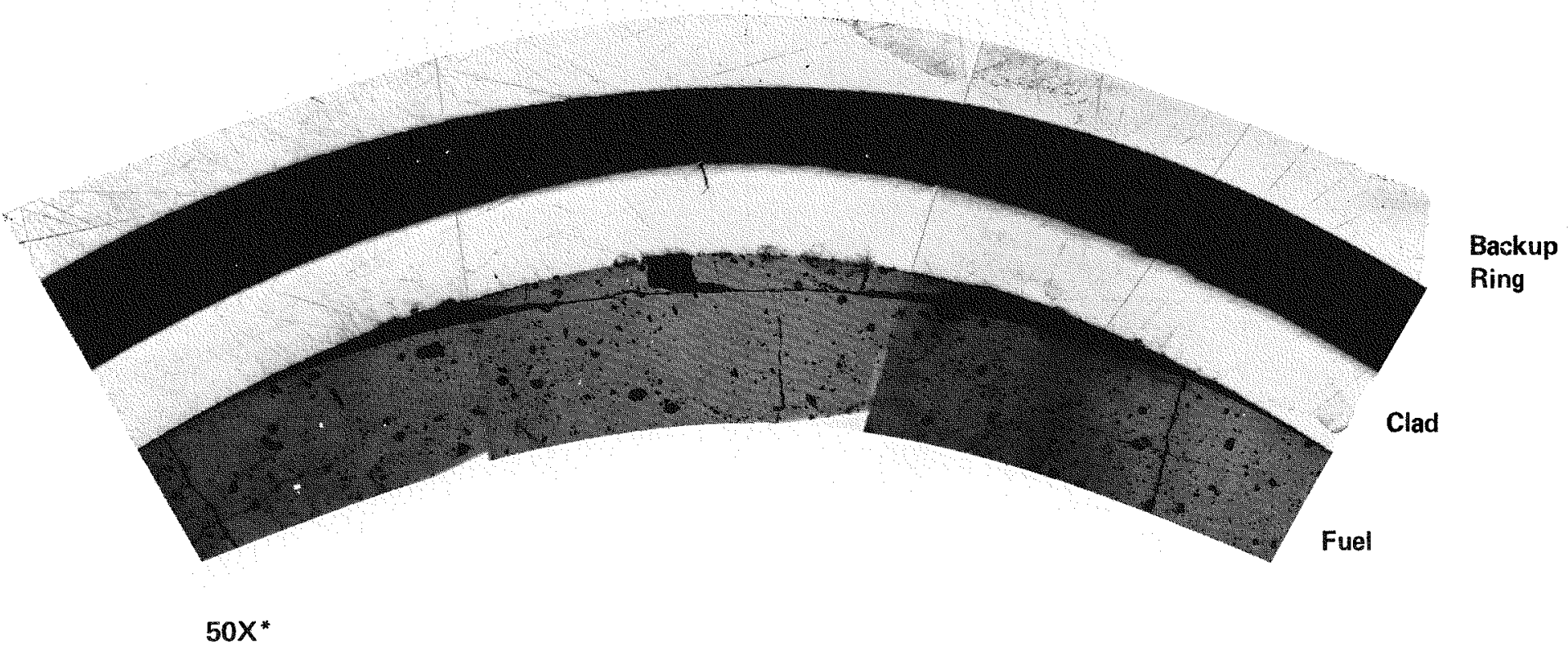

FIGURE 23. Photo Montage Of Incipient Cladding Crack Observed In Rod $157 E 01$ At $\sim 35-3 / 4$ Inches From Rod Bottom

* Please note that the illustration(s) on this page have been reduced $10 \%$ in printing. 


\subsubsection{Identification of Incipient Cracks in Batch 7 Rods. To determine if}

batch 7 rods were also susceptible to cracking, one metallographic specimen from rod 595A10 was examined. This specimen contained the location of an eddy current signal and a local diameter increase. Two cladding cracks were found in this specimen, and again the cracks appear to be caused by a fuel chip wedged in the fuel-clad gap. Figures 24 and 25 show the appearance of the crack at different magnifications.

The characteristics of the incipient cracks observed in the four specimens (from batch 8 and batch 7 ) were very similar. Results of the metallographic examinations can be summarized as follows:

- Cladding cracks were observed in both batch 7 and 8 rods; all cracks were intergranular, initiating at the outer surface.

- In all cases, the cracks were associated with a fuel chip wedged in the fuel-clad gap.

- The cracks were branched and had the typical appearance of intergranular stress corrosion cracks.

- In some cases, the cracks appeared to contain corrosion products.

- The cladding cracks were not seen adjacent to fuel pellet cracks.

- The cracks were unrelated to the seam weld in the cladding

- In batch 8 fuel rod specimens, no visible fuel-clad gap existed except in the vicinity of the fuel chip.

- Batch 8 fuel pellets showed circumferential cracking near the periphery of the pellet. Such cracking was not apparent in the batch 7 fuel rod.

\subsubsection{Relating Incipient Cracks to Cladding Splits. To obtain data relating} the incipient cracks described above to the long splits observed in the failed fuel rods, metallographic samples were obtained from failed rod 013E03. This rod was found to contain two short cracks (5 inches and 1-1/2 inches long) at two separate locations. The two cracks were axially separated by almost 4 feet and appeared to be independent of each other. One specimen from the location of the smaller crack was examined metallographically. The results showed the presence of a fuel chip at the location of the cladding split. Figure 26 shows the appearance of the fuel chip and the split in the cladding. The cladding also contained a number of small crack branches radiating inward, suggesting that the split had originated on the outer surface. Also, several tight cracks originating on the outer surface of the cladding were observed, thereby confirming the crack 


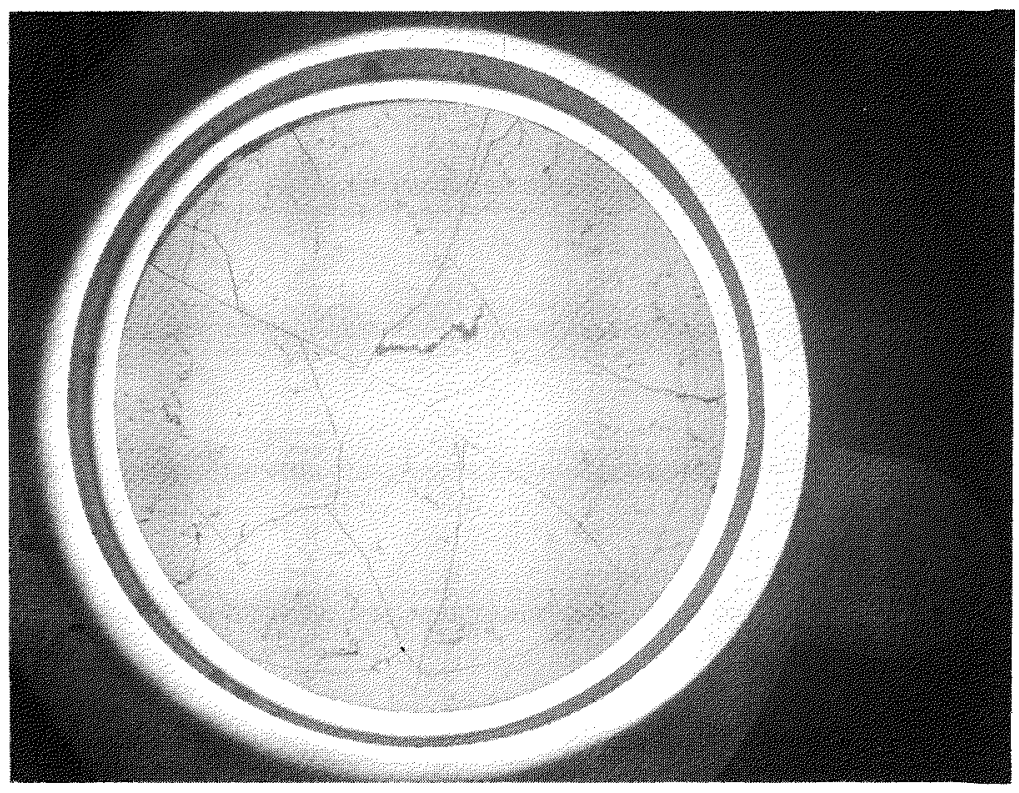

$7 X^{*}$

FIGURE 24. Photomacrograph Showing The Location Of Fuel Chip In Batch 7 Fuel Rod 595A10

* Please note that the illustration(s) on this page have been reduced $10 \%$ in printing. 


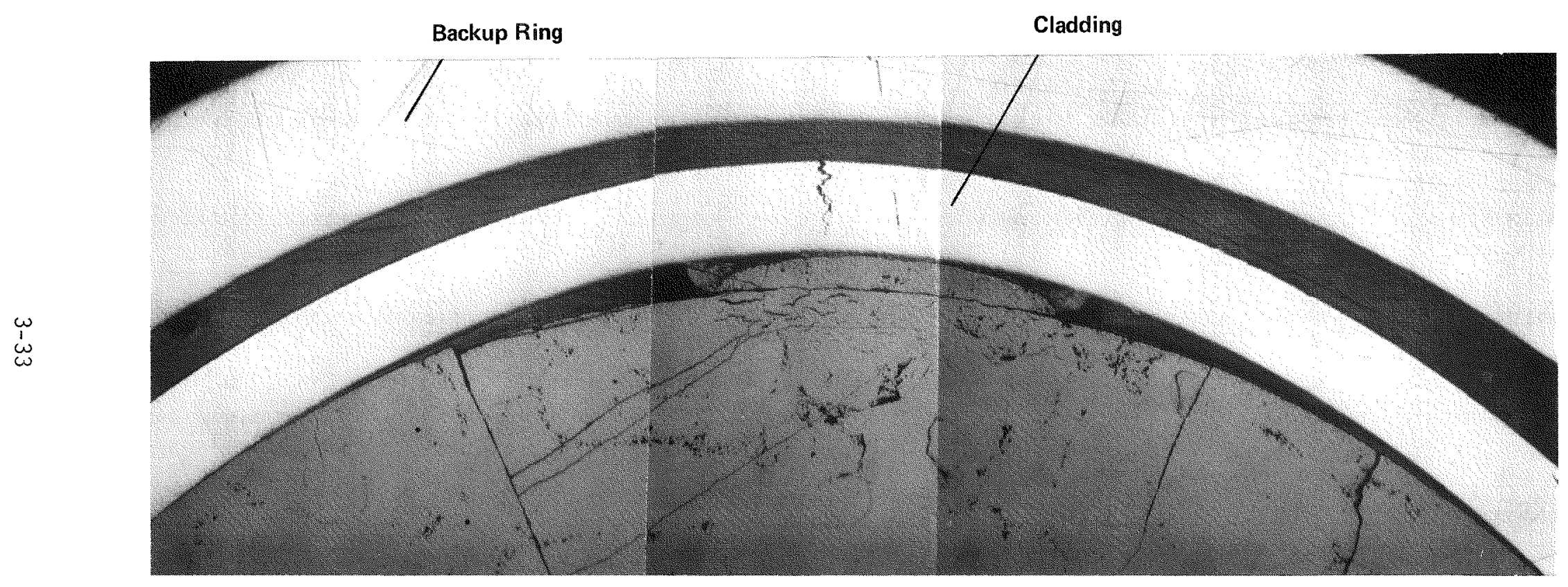

$35 X^{*}$

FIGURE 25. Appearance Of Cladding Crack And Fuel Chip In Batch 7 Fuel Rod 595A 10

* Piease note that the illustration(s) on this page have been reduced $10 \%$ in printing. 


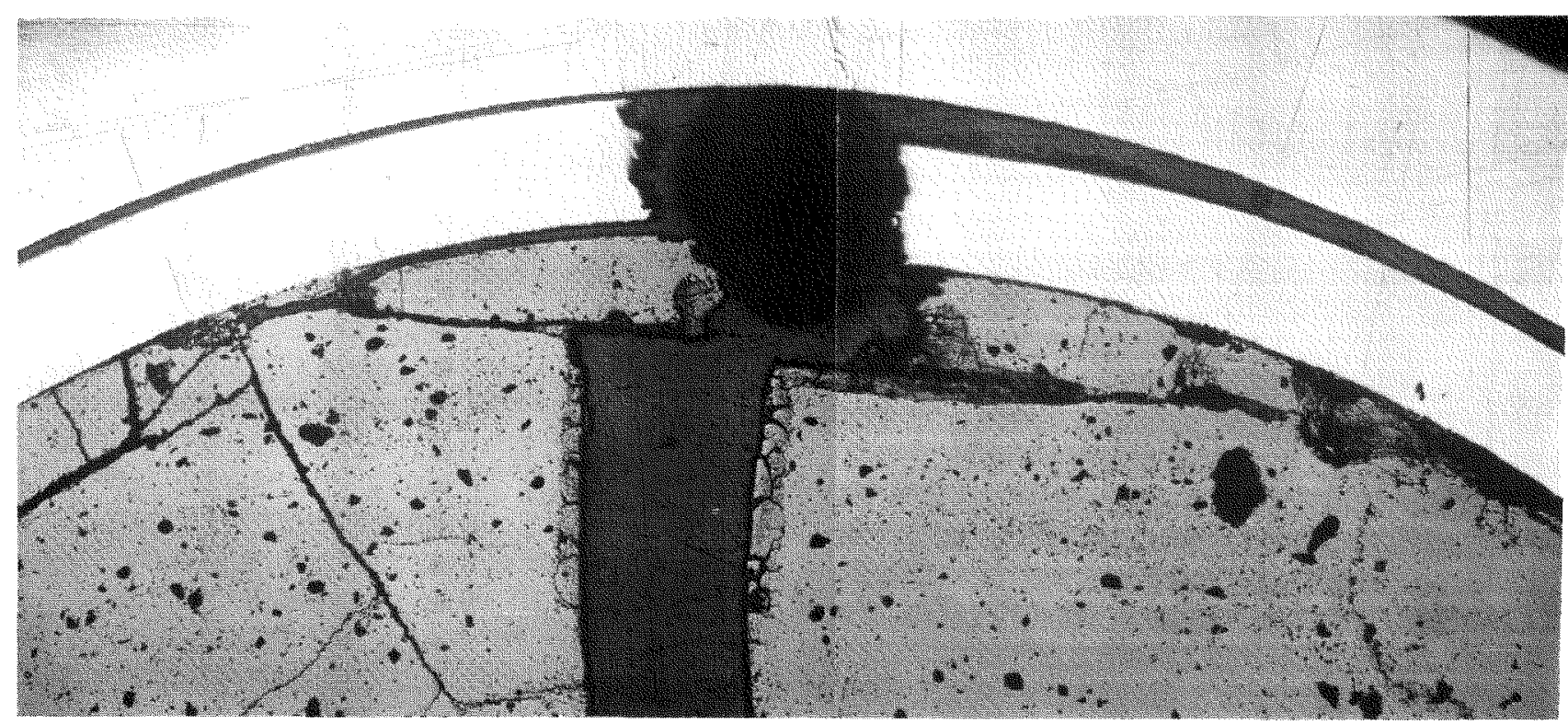

$35 X^{*}$

FIGURE 26. AREA OF TIGHT THRUWALL CRACK IN FAILED ROD $013 E 03$ SHOWING CHIP IN GAP

* Please note that the illustration(s) on this page have been reduced $10 \%$ in printing. 
characteristics to be very similar to the incipient cracks. Figures 27 and 28 show a crack branch and a small part-wall crack originating on the outer surface.

The fuel microstructure at the location of a cladding split was examined in detail. The $\mathrm{UO}_{2}$ fuel appeared to be highly oxidized, with significant separation at the grain boundaries. The distribution of fuel porosity was also unusual in that the pores were radially oriented towards the pellet center. However, no columnar grain structure was evident. Figure 29 shows the appearance of oxidized fuel near the cladding split. Figure 30 shows the radially oriented fuel porosity. Significant oxidation of fuel by reaction with water and an associated volume increase of fuel, as well as a reduction in fuel thermal conductivity, may have contributed to the formation of the long clad splits. It is also possible that several of the independently formed short splits may have joined axially to cause the long splits observed on the failed rods.

\subsubsection{Scanning Electron Microscope Examination of an Incipient Crack. One of} the metallographic specimens containing two incipient cracks was examined by using a scanning electron microscope in order to examine the crack tips at higher magnification. A thin ring of the specimen was cut from the metallographic specimen and examined in the as-polished condition. The crack tips were quite sharp, as shown in Figure 31 , suggesting that corrosion of the crack surface was not significant in this region.

Subsequently, the crack surface was exposed by breaking the specimen along one of the cracks. Figure 32 shows the fracture appearance. Attempts were made to determine the composition of the particles on the fracture surface using the energy dispersive $X$-ray system. However, no meaningful results could be obtained due to the high radiation background.

\subsubsection{Longitudinal Metallography of a Specimen from a Batch 7 Fuel Rod.} Results from gamma scanning of the high burnup batch 7 fuel rod had indicated the possibility of dish closure (presumably due to fuel swelling and/or fuel plasticity). The gamma activity profile in this rod did not show activity depressions at pellet interfaces in the high burnup region. To determine whether the fuel pellet dishes had been filled in due to fuel swelling, one longitudinal metallographic sample was examined from the high burnup region. The results of this examination showed that the absence of activity depression was simply due to 


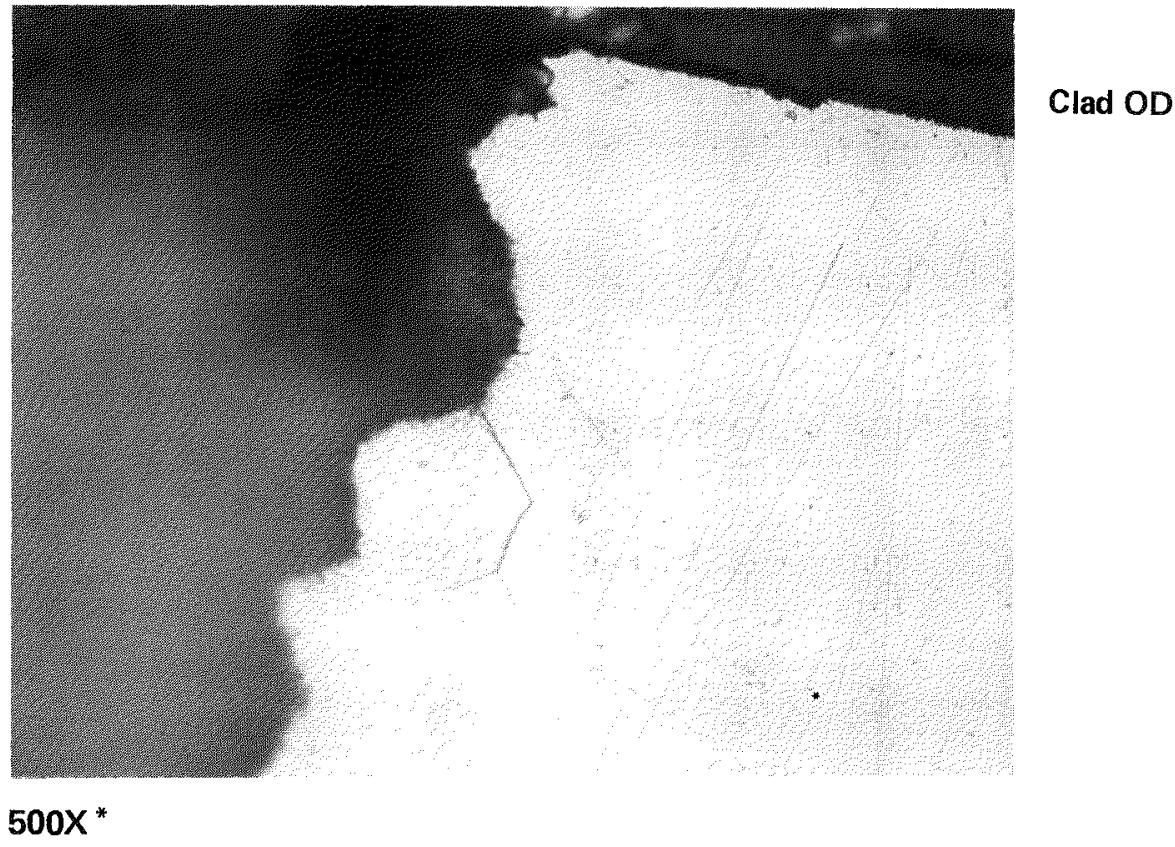

FIGURE 27. Photograph Showing A Crack Branch

Propagating Inward Suggesting The

Origin Of The Crack Shown In

Figure 26 To Be At The Fuel Rod

Outer Surface

* Please note that the illustration(s) on this page

have been reduced $10 \%$ in printing. 


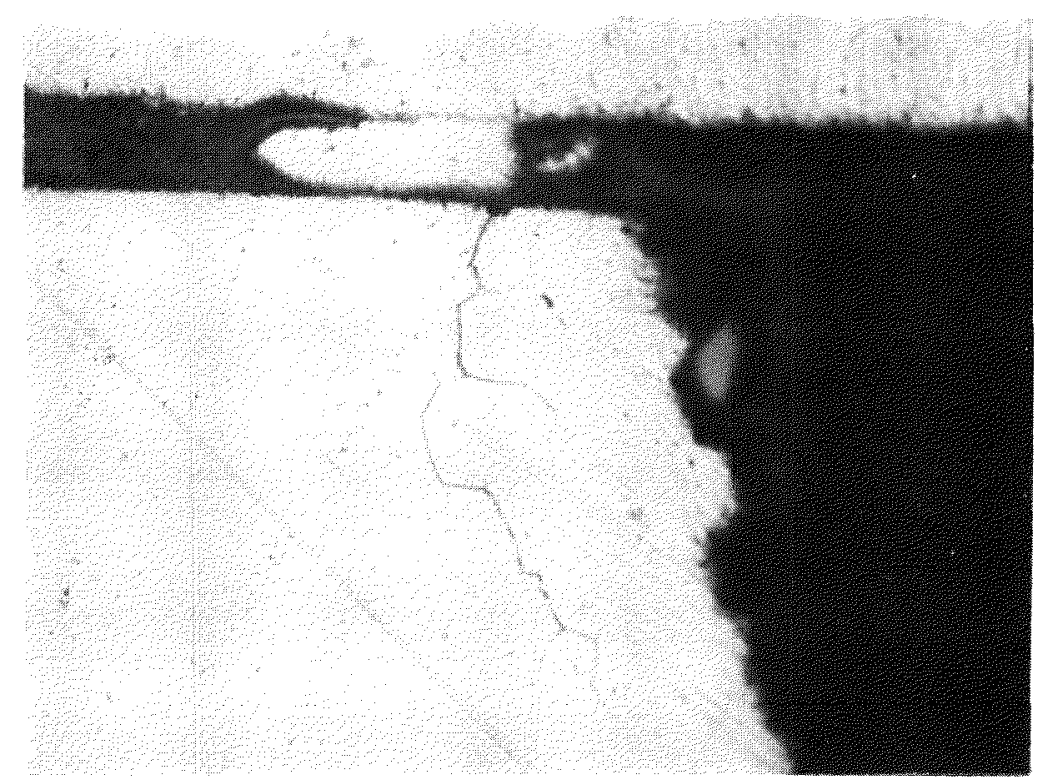

$500 X^{*}$

FIGURE 28. SMALL TIGHT CRACK ORIGINATING AT OD ADJACENT TO THE CLADDING SPLIT SHOWN IN FIGURE 26.

*Please note that the illustration(s) on this page have been reduced $10 \%$ in printing. 


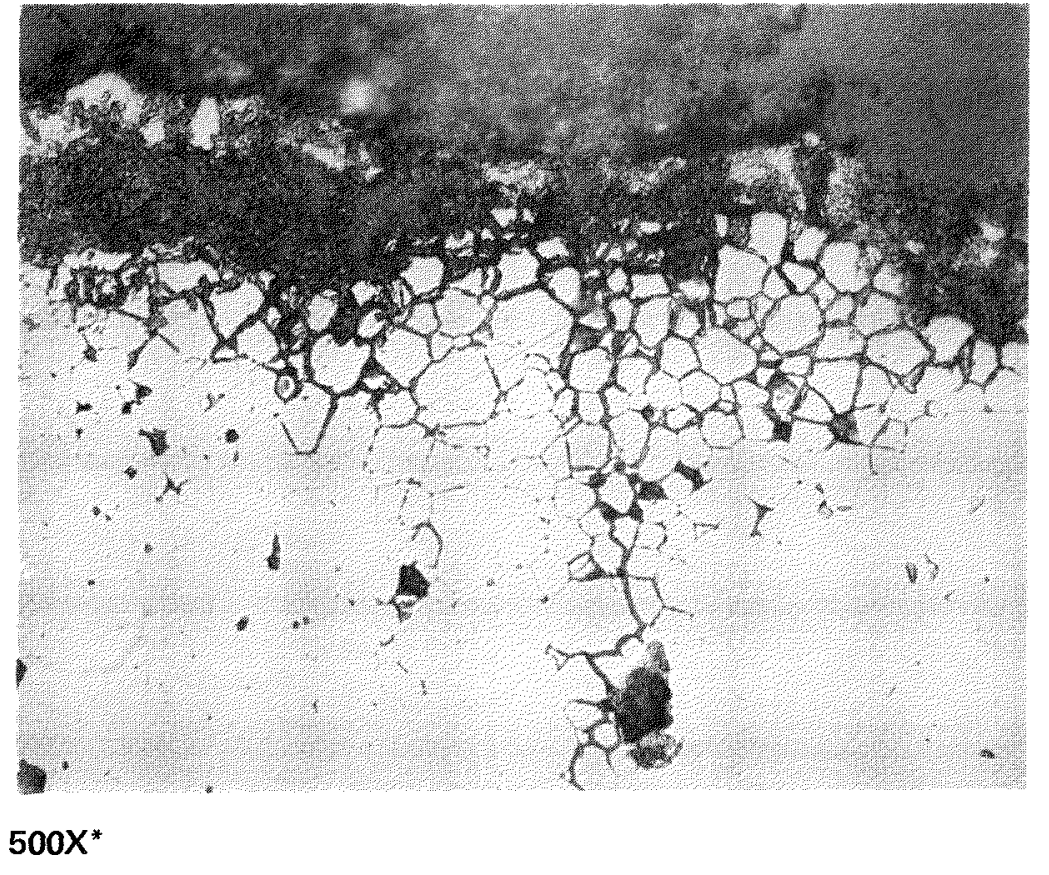

FIGURE 29. Oxidized $\mathrm{UO}_{2}$ Fuel At The Grain Boundaries In The Vicinity Of Cladding Split In Failed Fuel Rod $013 E 03$

*Please note that the illustration(s) on this page have been reduced $10 \%$ in printing. 


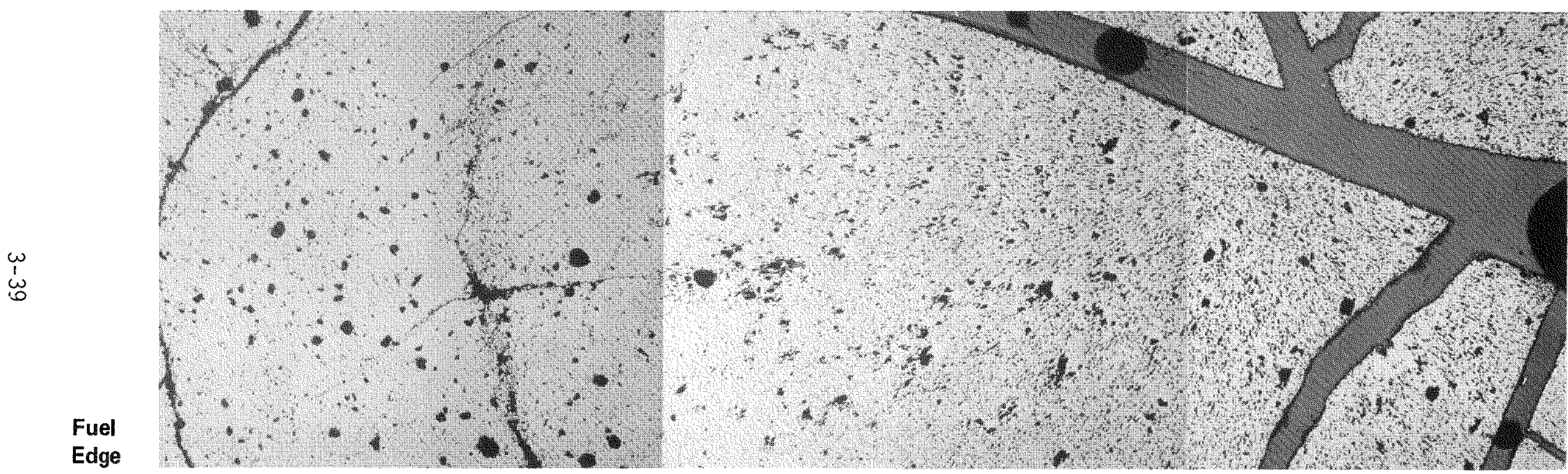

$40 X^{*}$

FIGURE 30. Appearance Of Fuel Porosity At The Location Of Cladding Failure In Rod $013 E 03$

* Please note that the illustration(s) on this page have been reduced $10 \%$ in printing. 


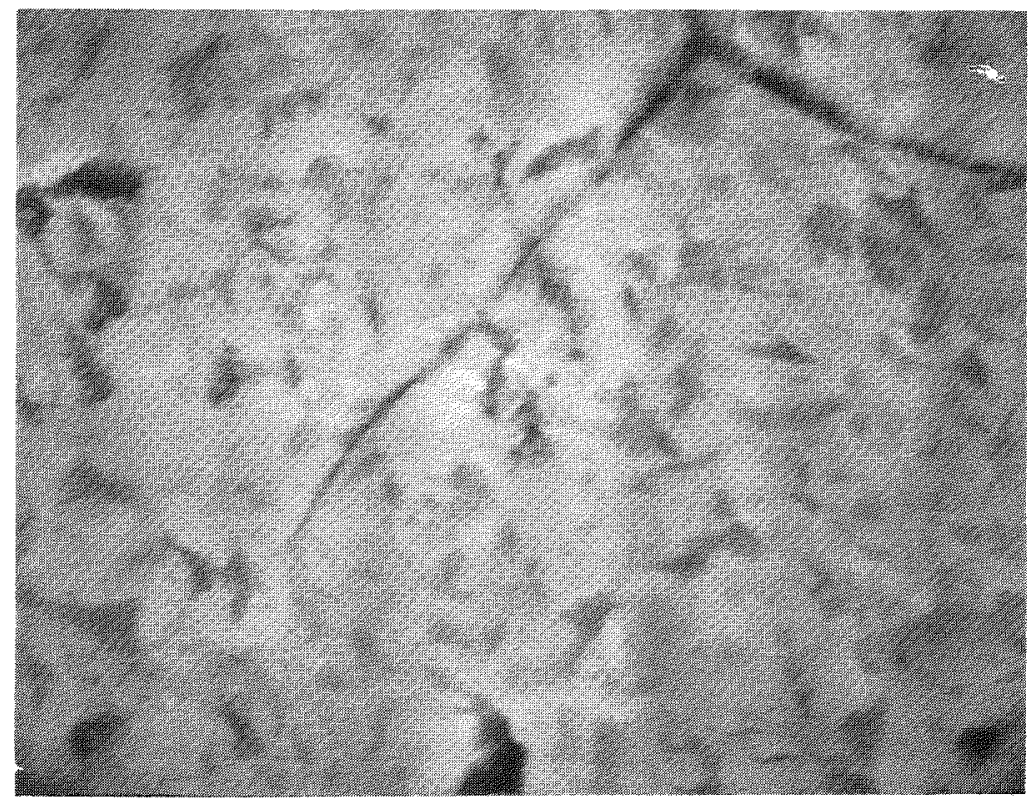

$6100 x^{*}$

FIGURE 31. HIGHER MAGNIFICATION APPEARANCE OF CRACK BRANCH TIP

* Please note that the illustration(s) on this page have been reduced $10 \%$ in printing. 


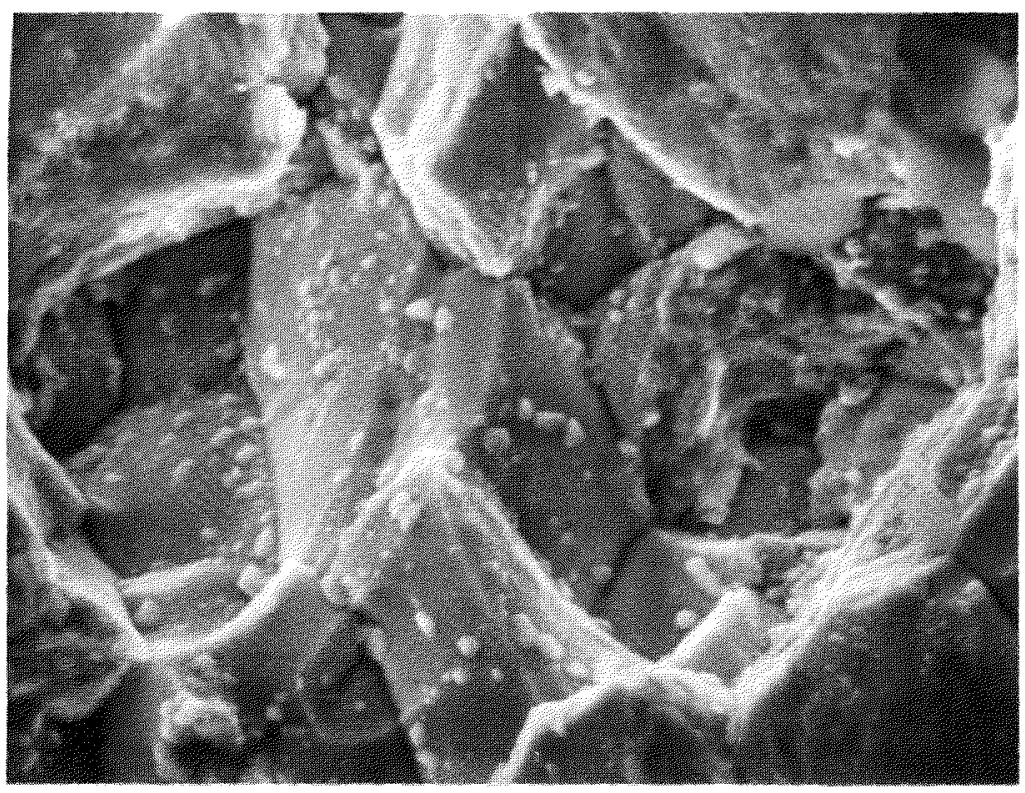

$6100 X^{*}$

FIGURE 32. HIGHER MAGNIFICATION APPEARANCE OF BRITTLE FRACTURE SURFACE

*Please note that the illustration(s) on this page have been reduced $10 \%$ in printing. 
relocation of fuel fragments into the dish. The profile of the dish was similar to that of the as-fabricated condition, as shown in Figure 33.

\subsubsection{Fuel Density Measurements}

Density measurements were made on fuel samples from batch 7 and batch 8 fuel rods to compare densification/swelling behavior of the two types of fuel. Each sample was obtained from a 1/2-inch-long fuel rod section. Essentially all the fuel pieces within the section were used in the measurement. The axial location of each sample was selected to provide data over a range of fuel burnups.

Density measurements were made by using the BCL mercury pycnometer. A cylindrical stainless steel standard was used to validate the procedure.

Figure 34 shows the results of density measurements on both batch 7 and batch 8 fuel samples. Results are shown as a function of burnup, in terms of percent of peak burnup in the batch 8 rod based on gamma scan profile. Also shown are approximate sample burnups. The data obtained are also shown in Table 8 . It can be seen that for a given burnup level the batch 8 fuel samples consistently show lower densities (by about 1 percent). The data also suggest that the batch 7 samples may have densified more than batch 8 fuel early in life. The rate of swelling as determined from the data appears to be about 1 percent per 10,000 MWD/MTU, which is consistent with that reported by others( 7 ).

Limited density data were also obtained on fuel samples from the qualification assembiy s004. This assembly apparently contained highly densifying fuel and the irradiated density values were 0.25 percent higher at peak burnup and 2.0 percent higher at low burnup than the as-fabricated density of 93.2 percent TD( 1 ). 


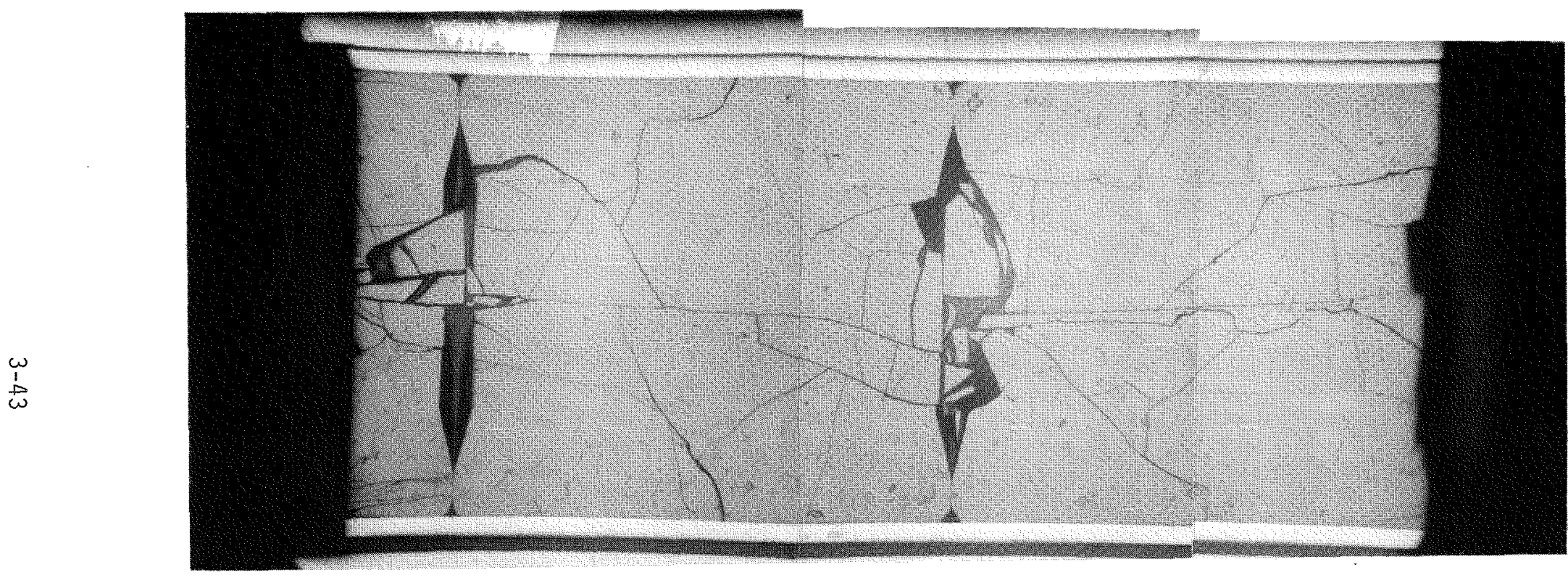

$7 X^{*}$

FIGURE 33. Photomacrograph Of Longitudinal Sample From Batch 7 Fuel Rod 595A10 Showing Axial Relocation Of Fuel Pieces Into The Dish

${ }^{\star}$ Please note that the illustration(s) on this page have been reduced $10 \%$ in printing 


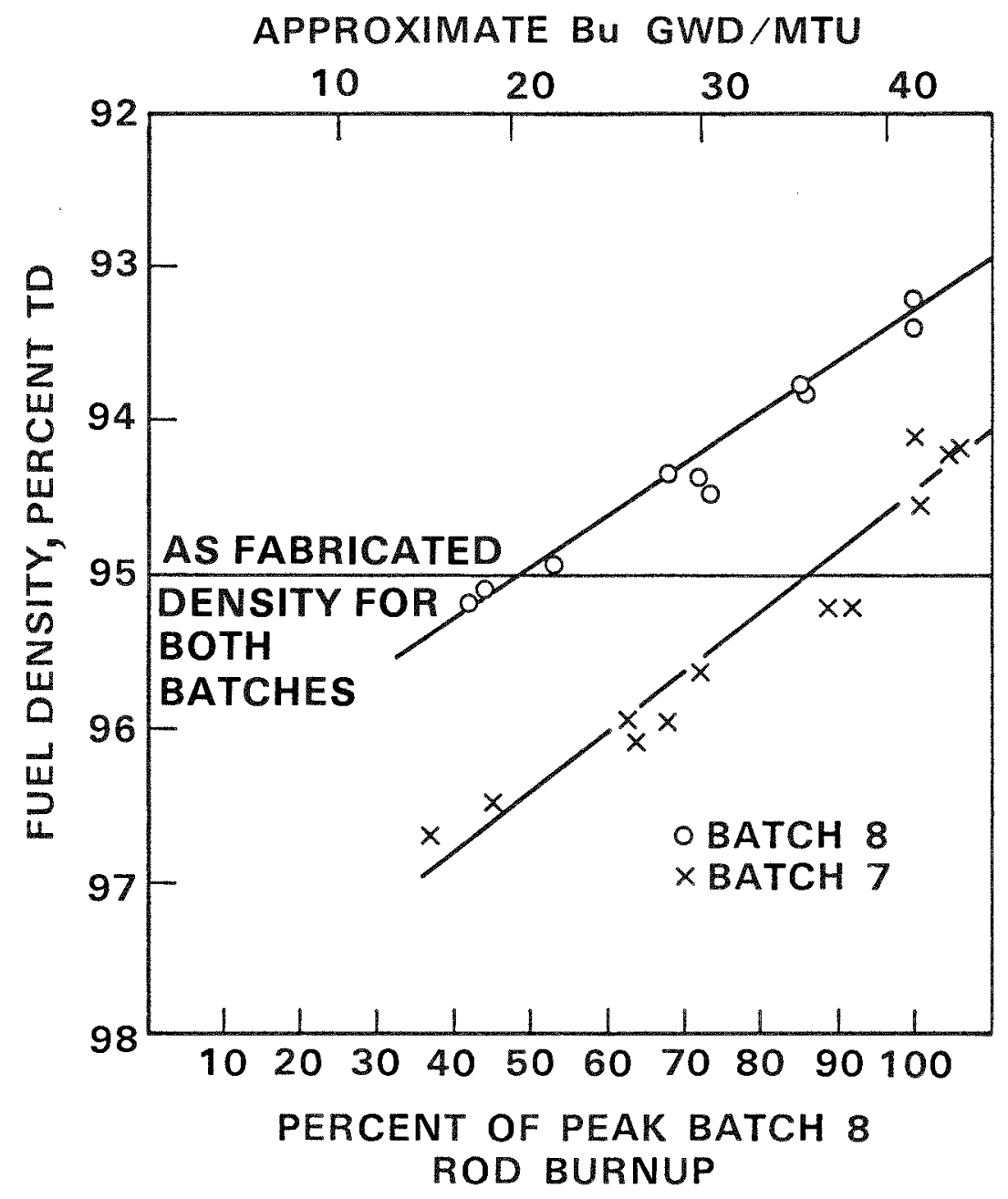

FIGURE 34. Results Of Irradiated Fuel Density Measurements On Samples From Batches 7 And 8 Fuel Rods 
TABLE 8

SUMMARY OF IRRADIATED FUEL DENSITY MEASUREMENTS

\begin{tabular}{|c|c|c|c|c|}
\hline Fuel Rod/Batch & $\begin{array}{c}\text { Axial Location } \\
\text { Inches from Rod Bottom }\end{array}$ & $\begin{array}{l}\text { Approx Burnup* } \\
\text { MWD /MTU }\end{array}$ & $\begin{array}{c}\text { End-of-Life } \\
\text { Density } \\
\% \text { TD }\end{array}$ & $\begin{array}{c}\text { Density } \\
\text { Change } \dagger \\
\% \text { TD }\end{array}$ \\
\hline \multirow[t]{10}{*}{ 217E02/Batch 8} & $114-115$ & 28,400 & 94,32 & -0.68 \\
\hline & $6-6.5$ & 30,500 & 94.38 & -0.62 \\
\hline & $76.5-77$ & 42,250 & 93.42 & -1.58 \\
\hline & $1-1.5$ & 17,750 & 95.20 & +0.20 \\
\hline & $2-2.5$ & 22,300 & 94.96 & -0.04 \\
\hline & $5.5-6.0$ & 30,800 & 94.50 & -0.50 \\
\hline & $46.5-47$ & 42,250 & 93.24 & -1.76 \\
\hline & $109-109.5$ & 35,900 & 93.8 & -1.20 \\
\hline & $109.5-110$ & 35,900 & 93.8 & -1.20 \\
\hline & $119-119.5$ & 18,600 & 95.14 & +0.14 \\
\hline \multirow[t]{12}{*}{$595 \mathrm{~A} 10 /$ Batch 7} & $76-76.5$ & 42,000 & 94.13 & -0.87 \\
\hline & $77.5-78$ & 42,400 & 94.54 & -0.46 \\
\hline & $6-6.5$ & 30,500 & 95.62 & +0.62 \\
\hline & $2-2.5$ & 19,000 & 96.47 & +1.47 \\
\hline & $44.75-45.25$ & 44,200 & 94.25 & -0.75 \\
\hline & $1-1.5$ & 15,500 & 96.70 & +1.70 \\
\hline & $45.25-45.75$ & 44,200 & 94.25 & -0.75 \\
\hline & $5.5-6.0$ & 28,700 & 95.95 & +0.95 \\
\hline & $115-115.5$ & 26,500 & 96.09 & +1.09 \\
\hline & $107.5-108$ & 37,600 & 95.26 & +0.26 \\
\hline & $114.5-115$ & 26,500 & 95.99 & +0.99 \\
\hline & $108-108.5$ & 37,600 & 95.24 & +0.24 \\
\hline
\end{tabular}

*Based on rod average burnups of 36,740 MWD/MTU for rod 217E02 and 38,400 for rod 595A10 and peak to average value of 1.15 .

†Based on as fabricated density of $95.0 \%$ TD. 
-

- 
Section 4

DISCUSSION

Over the years that stainless steel cladding has been used in commercial reactors, there have been few instances of fuel rod failures. The majority of failures in stainless steel cladding were in boiling water reactor environments. An extensive investigation of these failures had been performed by Duncan et al. ( 9 ) under the joint US-EURATOM research program. The investigation proved that highly stressed unsensitized austenitic stainless steels (such as Type 304) are susceptible to stress-assisted intergranular corrosion in high purity water environments. It appears that the failure mechanism was well understood and was believed to involve the following elements:

- Highly localized cladding stresses resulting from pellet-clad interaction.

- Segregation of impurity elements at grain boundaries during reactor operation.

- Irradiation-induced defects, such as vacancies in the cladding, which enhance grain boundary susceptibility by migrating to the grain boundaries along with the impurity atoms.

- Accumulation of harmful species such as chloride ions at the claddingwater interface.

In pressurized water reactor (PWR) environments such as the Connecticut Yankee reactor, Type 304 stainless steel cladding has performed well. In fact, there have only been four documented cases of fuel rod failures under PWR conditions. These were failures in the PM-3A core (10) (portable reactor in Alaska), in the APPR core from an Army reactor(11), in high burnup rods in the core of the BR-3 Vulcain reactor(12) and in the French/Belgian SENA reactor(13). Failures observed in the Connecticut Yankee reactor were not directly comparable to the PM-3A or $A P P R$ observations in that the design of the fuel rods and the operating parameters were quite different. The PM-3A core consisted of annular fuel tubes made from 30-mil-thick $\mathrm{UO}_{2}$-stainiess steel dispersion clad with 7-mi1-thick Type 347 stainless steel. The cladding was bonded to the fuel. Peak burnup in the fuel was approximately 50,000 MWD/MTU. The APPR fuel was of plate geometry with $\mathrm{UO}_{2}$ and $\mathrm{B}_{4} \mathrm{C}$ in a stainless steel matrix, roll bonded with Type 304 stainless 
steel cladding. Cracks observed in these cases were intergranular, initiating on the outer surface.

In the Vulcain core of the BR-3 reactor, the fuel rod failures were similar to the Connecticut Yankee fuel rod cracks. However, the rods (containing $\mathrm{UO}_{2}$ pellets in cold-worked Type 304 stainless steel) were irradiated at significantly higher ratings to burnups $>40,000$ MWD/MTU. Peak heat ratings in the Vulcain fuel rods were approximately $11 \mathrm{kw} / \mathrm{ft}$ compared to the peak heat rating of 7 to $8 \mathrm{kw} / \mathrm{ft}$ in the batch 8 Connecticut Yankee fuel rods. The failures observed in SENA are probably comparable to those in the Connecticut Yankee, since both systems are commercial power reactors. However, no information on the cause of failures in SENA is available in open literature.

Results of the examinations performed on the Connecticut Yankee batch 7 and batch 8 fuel rods show that the key elements contributing to failure were (a) high local stresses from fuel chips and (b) fuel densification/swelling behavior. It has also been postulated that the power ramp experienced by the core near the end of cycle 7 (second cycle for batch 8 fuel) could have resulted in the initiation of cracking and the subsequent failures. Each of these possible contributors is discussed in some detail below.

\subsection{LOCAL CLAD STRESSES FROM FUEL PELLET CHIPS}

Four incipient cracks in unfailed rods were discovered by metallographic examinations, three in batch 8 fuel rods and one in a batch 7 fuel rod. All the metallographic specimens were selected on the basis of NDE results, namely profilometry and eddy current data. In each case the cladding crack(s) had all the characteristics of stress-assisted intergranular cracking. Also, a fuel chip was found to be wedged in the fuel-clad gap at the same azimuthal orientation as the crack(s). High local clad strains as determined by profilometry data (in the nonrotating mode) and the presence of a fuel chip strongly suggest that the fuel chip was the source of high local stresses leading to cracking.

It is possible, however, that cladding cracks could have formed at other locations without the presence of a fuel chip. These cracks would be expected at highly stressed cladding ridges at pellet interfaces. Such cracks may not have been detected by eddy current scans, since the defect signals would be masked by the strong responses to clad ridging. 
Results from the examination of a failed fuel rod showed that the cracking mechanism was the same as that in the unfailed rods. The presence of a fuel chip at the location of failure suggests that the chip was one of the key contributors to fuel rod failure.

It is important to note that cladding cracks associated with a fuel chip were observed in a batch 7 fuel rod. Yet there was no indication of fuel rod failure in batch 7. Further, it has been reported that fuel chipping was a common problem in the loading of previous batches of Connecticut Yankee fuel rods (14). These observations suggest that the fuel chips alone did not produce rod failures. Rather, it appears that fuel chips together with other factors, such as fuel swelling and possibly power ramping of the fuel, account for the failures.

\subsection{FUEL DENSIFICATION/SWELLING BEHAVIOR}

Irradiated fuel density measurements on samples from batch 8 and batch 7 fuel rods show a significant difference in the densification/swelling behavior of the two types of fuel. It appears that the batch 8 fuel densified by a negligible amount. compared to batch 7 fuel. Net swelling (swelling less densification) in high burnup batch 8 fuel samples was approximately 1.7 percent $\Delta V N$ while that in batch 7 was 0.9 percent $\Delta V / V$. The differences in the net swelling of 0.8 percent $\Delta V / V$ is equivalent to about a $1 \mathrm{mil}$ difference in the diametral fuel-clad gap. This suggests that the batch 8 fuel operated with a correspondingly smaller fuel-clad gap than the batch 7 fuel. Therefore, fuel-clad contact would have occurred earlier in the life of batch 8 fuel rods, resulting in higher clad stresses. This observation is consistent with other data obtained in this program. Clad ridging was found to be much sharper in batch 8 fuel. The fuel rod diameter profile over the length of the rod in batch 8 fuel rods also differed from that of batch 7 fuel rods. In batch 8 fuel rods the data indicate either a clad pushout in the rod midregion or an earlier arrest of clad creep. The metallographic data also indicate stronger fuel-clad contact in the batch 8 fuel sample. Further evidence of stronger fuel-clad contact in batch 8 fuel rods can be obtained from the fuel cracking pattern in that a circumferential crack was observed in the fuel pellet near the pellet periphery. The fuel-clad gap was absent in the batch 8 samples, while a small gap could be seen in the batch 7 sample.

The observed differences in the densification/swelling behavior between the batch 8 and batch 7 fuel types is consistent with the results from the examination of archive fuel pellets. In batch 8 fuel, 50-60 percent of the porosity was in the 
5-10 ${ }_{\mu} \mathrm{m}$ range while in batch 7 fuel 70-80 percent of the porosity was in the 1-5 $\mu \mathrm{m}$ range. The larger fraction of small pores $(1-5 \mu \mathrm{m})$ in the batch 7 fuel suggests that batch 7 fuel is more densifying than the batch 8 fuel. However, as noted in Figure 34, the rate of swelling of the fuel appears to be the same in both batches.

The irradiated density data are also consistent with the observed fission gas release fractions. In batch 8 fuel which showed little or no densification, fission gas release was less than 1 percent. In batch 7 fuel which appears to be slightly more densifying, higher gas release was observed. In the qualification assembly containing highly densifying fuel, release fractions of up to 14.3 percent were measured(8). Similar observations relating fuel densification and fission gas release have been made by other investigators $(\underline{6}, \underline{15})$.

\subsection{BNFL ANALYSIS OF CYCLE 7 POWER MANEUVER EVENT}

The operating history of batch 8 fuel was also examined for any departure from steady state full-power operation. The most significant departure was a 10-day period at 65 percent of full power near the end of cycle 7 (near the end of the second cycle for the batch 8 fuel). The reactor power was subsequently raised to 100 percent. Since a sharp increase in coolant activity was also noted at this point, it was suspected that this power ramp could have caused or initiated fuel rod failures.

Coolant activity continued to increase, and after cycle 8 operation was completed, BNFL performed an analysis of this particular power maneuver(16). The analysis was performed using the UK fuel performance code, SLEUTH-SEER. In order to expedite the analysis, a rough estimate of the irradiation history was used. In this analysis, peak clad stresses and strains were computed and compared with the known values of yield stress and ductility of the irradiated clad material. The results led to the conclusion that the failures in batch 8 fuel could have been caused by the power ramp towards the end of cycle 7. As a result, interim restrictions on the rate of power increase for the reactor were imposed to prevent additional failures during future operation. Details of this analysis are given in Reference 16 .

Although the effects of a pellet chip could not be treated in this analysis, it is thought that the presence of pellet chips would further decrease the available gap and aggravate clad stresses and strains, thereby increasing the probability of clad failure. 


\subsection{CAUSE OF FUEL ROD FAILURES}

From the discussion of the results presented above it appears that the key elements contributing to the failure of Connecticut Yankee batch 8 fuel rods are:

1. Highly localized cladding stresses resulting from the presence of fuel chips wedged in the fuel-clad gap.

2. Low propensity for fuel densification, leading to early gap closure and enhancement of fuel-clad contact pressure.

3. Power change maneuver at the end of cycle 7.

The contributions from the third element are not clear. The hot cell examination results in general indicate that fuel-clad contact pressure was much higher in batch 8 fuel rods than in batch 7 . This is believed to be due to the low propensity for in-reactor densification of the batch 8 fuel. Therefore, any additional contributions to the cladding stresses, such as fuel chips, may have been sufficient to cause failures. However, the possible effects of the power ramp cannot be ignored.

\subsection{USE OF RESEARCH RESULTS}

The experimental results described above indicate probable elements contributing to the Connecticut Vankee batch 8 fuel failures. These results also suggest directions for changes in key elements to improve the performance of future reload fuel batches. Since pellet chips are clearly implicated in the failures, attention has been directed to the fuel fabrication process. Selected fabrication changes have been made and additional surveillance programs implemented which are directed to mitigating the pellet chipping problem. An immediate benefit has been an improvement in pellet loading, with fewer instances of loading problems than in prior batches.

Other areas of possible change are specification of lower impurity levels in the cladding and fuel design changes to increase the pellet-to-clad gap. The lower clad impurity level would reduce stress corrosion susceptibility, and the increased gap would better accommodate any chips which might be present and would also better accommodate fuel swelling at high burnups. Minor "refinements" have been made within current specifications for batch 13 fuel (currently in fabrication). More extensive changes are being investigated analytically to optimize fuel design and performance for future reload batches. A larger gap size along with fuel prepressurization are anticipated for implementation in batch 14 . 
-

$\bullet$ 


\section{Section 5}

CONCLUSIONS

The results of the hot cell examinations presented in this report lead to the following conclusions.

(1) Unsensitized stainless steel cladding is susceptible to intergranular cracking in pressurized water reactor environments.

(2) Depending upon design and fabrication parameters, failure of the stainless steel cladding can occur under normal reactor operating conditions (i.e., peak heat ratings of $\sim 8 \mathrm{kw} / \mathrm{ft}$ ).

(3) The batch 8 fuel rod failure mechanism appears to be stress assisted intergranular corrosion, with the sources of stress being:

(a) a fuel pellet chip wedged in the fuel-clad gap

(b) high clad stresses induced by pellet-cladding interaction, their magnitude being dependent upon the densification/swelling behavior of the fue]

(c) possible power ramp effects following low power operation near the end of the second cycle of irradiation.

(4) The primary failures are probably short-axial cracks, with the observed splits caused by a fuel volume increase due to oxidation upon exposure to the coolant.

(5) Modification of the fuel rod design and fabrication process are necessary to avoid failures in future reload batches. An increase in the fuel-clad gap along with appropriate changes in the fuel rod loading process to reduce fuel chipping problems are expected to eliminate fuel rod failures in subsequent core reloads. 
-

- 
Section 6

REFERENCES

1. Letter reports from Connecticut Yankee Atomic Power Company to USNRC-CYH

79-093. February 28, 1979 and CYH 79-188 July 31, 1979, Docket No. 50-213.

2. M. Pitek. Northeast Utilities Service Company, private communication.

3. V. Pasupathi and R. W. Klingensmith. "Investigation of Fuel Rod Failures in the Connecticut Yankee Reactor", BCL-585-19 Interim Report, November 1980.

4. Babcock and Wilcox letter report. "Characterization of Connecticut Vankee Archive Fuel Pellets", LR:79:5016-01:1.

5. J. Prestwood and D. A. Banks. "The Measurement of Diameter of the Rods of $15 \times 15$ PWR Fuel Assemb7ies in the Spent Fuel Pool of the Connecticut Yankee Reactor, Haddam Neck, from 17-24 May 1979".

6. S. R. Pati. "Gas Release and Microstructural Evaluation of Three Cycle Fuel Rods From Calvert Cliffs -1". C-E NPSD-119, December, 1980.

7. H. Assmann and R. Manzel. "The Matrix Swelling Rate of $\mathrm{UO}_{2}$ ", J. Nuclear Materials, 68, (1977), p 360-364.

8. D. C. Langstaff, W. J. Bailey, A. B. Johnson, and M. P. Landow, "Examination of Stainless-Steel-Clad Connecticut Yankee Fuel Assembly, S004, After Storage in Borated Water, PNL-3828, to be issued.

9. R. N. Duncan. "Stainless Steel Failure Investigation Program", final summary report: EURAEC-GEAP 5530, February, 1968.

10. J. B. Brown, Jr., V. W. Storhok, and J. E. Gates. "Postirradiation Examination of the PM-3A Type 1 Serial 2 Core", ANS Transactions, 1967, p 668-669.

11. L. D. Schaffer. "Army Reactors Program Progress Report", ORNL 3231, January 1962.

12. J. Storre and D. H. Locke. "High Burnup Irradiation Experience in Vulcain", Nuclear Engineering International, February 1970, p 93-99.

13. I. Multer. "European Operating Experience", paper presented at the joint topical meeting on Commercial Nuclear Fuel Technology Today. Toronto, Canada. April 1975.

14. M. Pitek. Northeast Utilities Service Company, Private communication.

15. N. Fuhrman and V. Pasupathi. "Evaluation of Fuel Rod Performance in Maine Yankee Core I", EPRI-NP-812, March 1976. 
16. D. A. Howl and L. F. Raven. "A Review of the Fuel Failures in Batch 8 Fuel From the Haddam Neck Reactor." Paper presented in IAEA specialists meeting on Pel let Cladding Interactions in Water Reactors, Riso, Denmark, September 1980. 


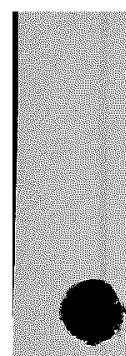

O

. 
